$10 / 3.192850$

•

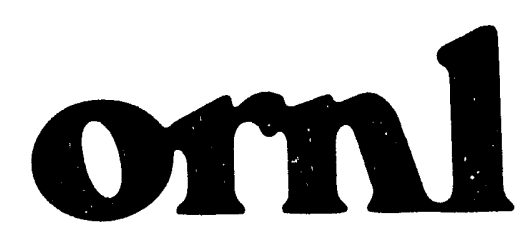

ORNL-6694

OAK RIDGE

NATIONAL

LABORATORY

MARTIN MARUETIA

\section{The Cost of Silicon Nitride Powder: What Must It Be To Compete?}

Sujit Das

T. Randall Curlee 
This report has been reproduced directly from the best avaliable copy.

Available to DOE and DOE contractors from the Office of Scientific and Technical Information, P.O. Box 62, Oak Ridge, TN 37831; prices available from (615) 576-8401, FTS 626-8401.

Available to the public from the National Technical Information Service, U.S. Department of Commerce, 5285 Port Royal Rd., Springfield, VA 22161.

This report was prepared as an account of work sponsored by an agency of the United States Government. Neither the United States Government nor any agency thereof, nor any of their employees, makes any warranty, express or implied, or assumes any legal liability or responsibility for the accuracy, completeness, or usefulness of any information, apparatus, product, or process disclosed, or represents that its use would not infringe privately owned rights. Reference herein to any specific commercial product, process, or service by trade name, trademark, manufacturer, or otherwise, does not necessarily constitute or imply its endorsement, recommendation, or favoring by the United States Government or any agency thereof. The views and opinions of authors expressed herein do not necessarily state or reflect those of the United States Government or any agency thereof. 


\title{
THE COST OF SILICON NITRIDE POWDER: WHAT MUST IT BE TO COMPETE?
}

\author{
Sujit Das \\ and \\ T. Randall Curlee
}

Energy and Economic Analysis Section

Energy Division

Oak Ridge National Laboratory

Date Published -- February 1992

Prepared for the

Assistant Secretary for Conservation and Renewable Energy

Office of Transportation Technologies

Prepared by the

OAK RIDGE NATIONAL LABO: ATORY

Oak Ridge, Tennessee $378 ; 1$

managed by

MARTIN MARIETTA ENERGY SYSTEMS, INC.

for the

U.S. DEPARTMENT OF ENERGY

under contract DE-AC05-84OR21400 


\section{TABLE OF CONTENTS}

LIST OF TABLES $\ldots \ldots \ldots \ldots \ldots \ldots \ldots \ldots \ldots \ldots \ldots \ldots \ldots \ldots \ldots \ldots \ldots$

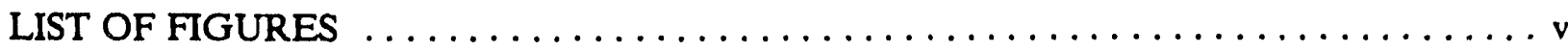

ACKNOWLEDGEMENTS $\ldots \ldots \ldots \ldots \ldots \ldots \ldots \ldots \ldots \ldots \ldots \ldots$ vii

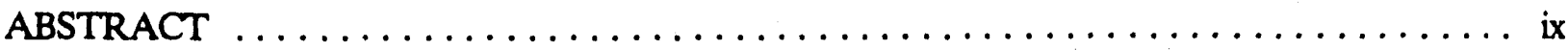

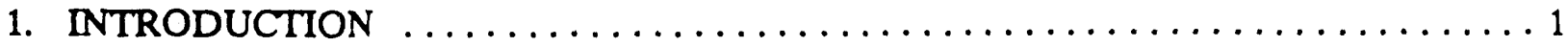

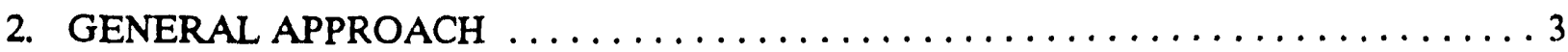

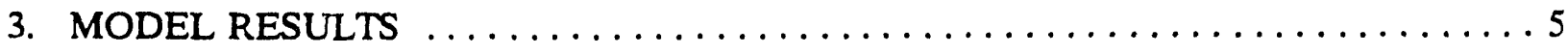

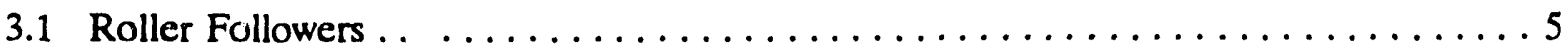

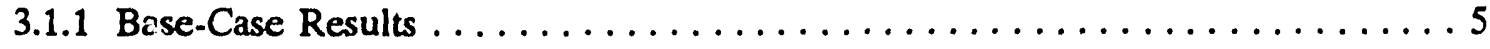

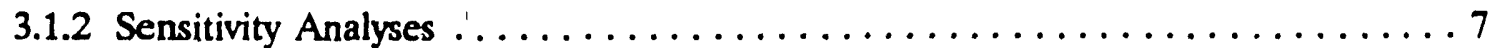

3.1.2.1 Total Yield vs Follower Cost ..................... 7

3.1.2.2 Production Volume vs Follower Cost $\ldots \ldots \ldots \ldots \ldots \ldots \ldots$

3.1.2.3 Grinding Rate vs Follower Cost $\ldots \ldots \ldots \ldots \ldots \ldots \ldots \ldots \ldots$

3.1.3 Powder Cost Reductions in Combination with Other

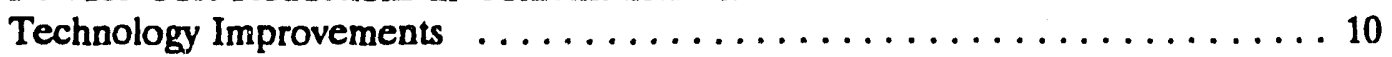

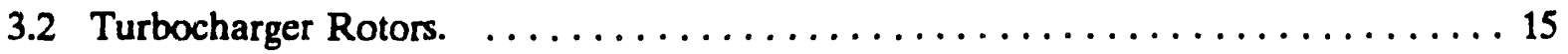

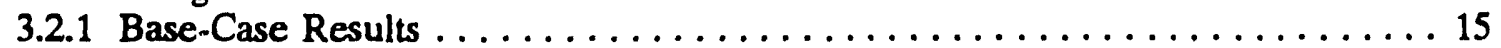

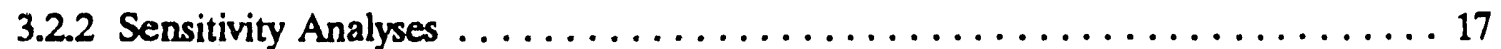

3.2.2.1 Production Volume vs Turbocharger Cost . . . . . . . . . . 17

3.2.2.2 Total Yield vs Turbocharger Cost . . . . . . . . . . . . . . . 17

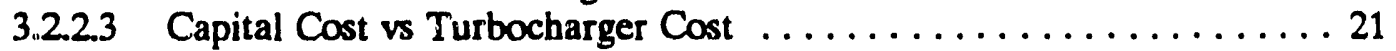

3.2.2.4 Grinding Rate vs Turbocharger Cost ................. 21

3.2.3 Powder Cost Reductions in Combination with Other

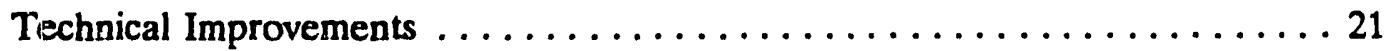

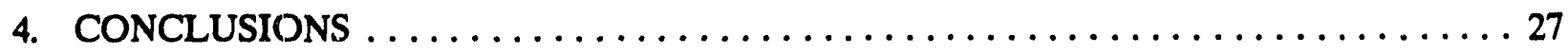

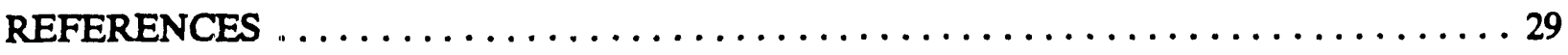

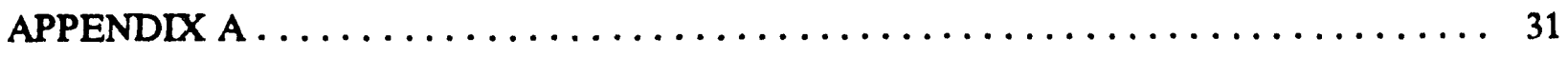

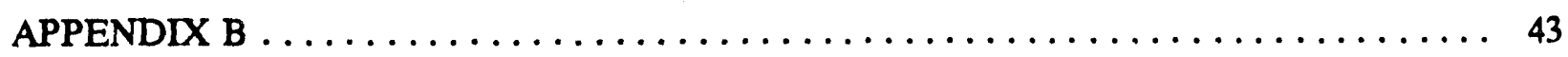


Table 3.1 Base-case assumptions for roller followers $\ldots \ldots \ldots \ldots \ldots \ldots \ldots \ldots \ldots \ldots$

Table 3.2 Base-case assumptions for turbocharger rotors $\ldots \ldots \ldots \ldots \ldots \ldots \ldots \ldots$

\section{LIST OF FIGURES}

Figure 3.1 Estimated base-case cost of manufacturing silicon nitride roller followers $\ldots \ldots 6$

Figure 3.2 Sensitivity of follower cost to changes in powder $\cos t \ldots \ldots \ldots \ldots \ldots \ldots$

Figure 3.3 Sensitivity of follower cost to changes in total yield $\ldots \ldots \ldots \ldots \ldots \ldots$

Figure 3.4 Sensitivity of follower cost to changes in production volume $\ldots \ldots \ldots \ldots \ldots$

Figure 3.5 Sensitivity of follower cost to changes in grinding rate $\ldots \ldots \ldots \ldots \ldots \ldots$

Figure 3.6 Sensitivity of follower cost to changes in silicon nitride powder

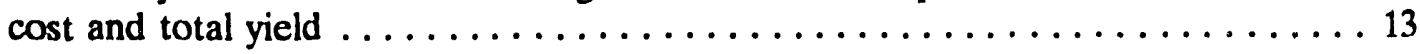

Figure 3.7 Sensitivity of follower cost to changes in silicon nitride powder

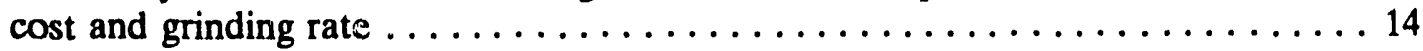

Figure 3.8 Estimated base-case cost of manufacturing silicon nitride turbocharger rotors $\ldots 16$

Figure 3.9 Sensitivity of turbocharger cost to changes in powder $\cos t \ldots \ldots \ldots \ldots$

Figure 3.10 Sensitivity of turbocharger cost to changes in production volume $\ldots \ldots \ldots 19$

Figure 3.11 Sensitivity of turbocharger cost to changes in total yield $\ldots \ldots \ldots \ldots \ldots \ldots$

Figure 3.12 Sensitivity of turbocharger cost to changes in capital cost $\ldots \ldots \ldots \ldots \ldots 22$

Figure 3.13 Sensitivity of turbocharger cost to changes in grinding rate $\ldots \ldots \ldots \ldots \ldots$

Figure 3.14 Sensitivity of turbocharger cost to changes in silicon nitride powder

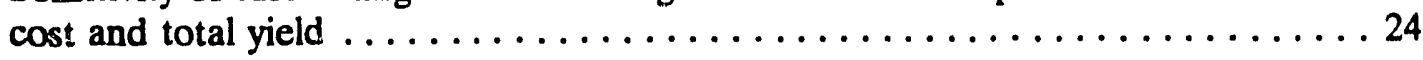

Figure 3.15 Sensitivity of turbocharger cost to changes in silicon nitride powder

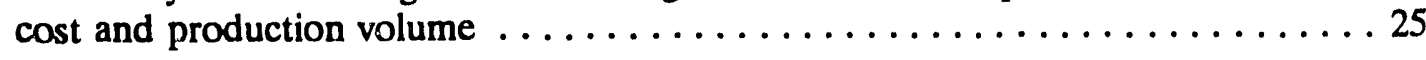




\section{ACKNOWLEDGEMENTS}

M. Srinivasan, Materials Solutions, NY and Dale Wittmer, Wittmer Consultants, Inc., IL previded helpful critiques and comments on the cost models used in our analysis. Pam Witcher did $?$ masterful job on word processing the manuscript. Their contributions are gratefully acknowledged.

Research sponsored by the U.S. Department of Energy, Assistant Secretary for Conservation and Renewable Energy, Office of Transportation Technologies, as part of the Ceramic Technology Project of the Materials Development Program, under contract DE-AC05-84OR21400 with Martin Marietta Energy Systems, Inc. 


\begin{abstract}
The ability of advanced ceramic components to compete with similar metallic parts will depend in part on current and future efforts to reduce the cost of ceramic parts. This paper examines the potential reductions in part cost that could result from the development of less expensive advanced ceramic powders. The analysis focuses specifically on two silicon nitride engine components -- roller followers and turbocharger rotors.

The results of the process-cost models developed for this work suggest that reductions in the cost of advanced silicon nitride powder from its current level of about $\$ 20$ per pound to about $\$ 5$ per pound will not in itself be sufficient to lower the cost of ceramic parts below the current cost of similar metallic components. This work also examines if combinations of lower-cost powders and further improvements in other key technical parameters to which costs are most sensitive could push the cost of ceramics below the cost of metallics. Although these sensitivity analyses are reflective of technical improvements that are very optimistic, the resulting part costs are estimated to remain higher than similar metallic parts.

Our findings call into question the widely-held notion that the cost of ceramic components must not exceed the cost of similar metallic parts if ceramics are to be competitive. Economic viability will ultimately be decided not on the basis of which part is less costly, but on an assessment of the marginal costs and benefits provided by ceramics and metallics. This analysis does not consider the benefits side of the equation. Our findings on the cost side of the equation suggest that the competitiveness of advanced ceramics will ultimately be decided by our ability to evaluate and communicate the higher benefits that advanced ceramic parts may offer.
\end{abstract}




\section{INTRODUCTION}

In recent years, advanced structural ceramics have made significant inronds into applications that have been served traditionally by metallics, such as biomaterials, wear parts, and cutting tools. Further encroachments into these and other markets dominated by metallics -- such as reciprocating engine components, heat exchangers, and bearings -- are expected. It is generally recognized, however, that the reliability and affordability of ceramics must be improved if ceramics are to become a widespread alternative to metallics. Sheppard (1991) suggests that successful commercialization of advanced ceramics depends on providing reliable components at competitive prices comparable in quality and price to their metallic counterparts.

Integrated cost-effective manufacturing is the major objective of many current $R \& D$ programs targeted at reducing the costs of ceramics. Finishing and machining operations to form a part to its final shape and nondestructive testing to ensure reliability constitute a major proportion of production costs. Therefore, the development of processes that can reliably fabricate a component to its final shape is crucial. To improve properties and reliability, various advanced ceramic processing technologies are currently under development, such as high-pressure processing, chemical processing, a combination of both, the direct metal oxidation process, and self-propagating high-temperature synthesis.

Other work is directed at reducing the cost of reproducible uniform quality powders needed to fabricate reliable advanced ceramic components with a minimum number of intermediate steps. Depending on the particular ceramic part, materials are estimated to currently contribute between $40 \%$ and $60 \%$ of total manufacturing cost (Rothman, 1985). Sheppard (1991) reports that several firms and research institutions (e.g., the Diamonite Products Division of W. R. Grace \& Co. and the U.S. Naval Research Laboratory) are currently addressing the possibility of manufacturing silicon nitride powder for low-temperature wear applications in the $\$ 5 / \mathrm{lb}$ price range. Silicon nitride powders suitable for advanced ceramic applications currently cost about $\$ 20 / \mathrm{b}$.

This paper focuses on the contribution that lower-cost powders could make toward improving the economic viability of advanced silicon nitride components as alternat"ves to similar metallic parts. For the purposes of this analysis, we accept Sheppard's assertion that ceramic parts must cost no more than similar metallic parts if ceramics are to compete. We therefore examine how much the cost of silicon nitride powder must be reduced in order for silicon nitride components to be "competitive" with similar metallic components. Realizing that reductions in powder cost may not alone be sufficient to insure the economic viability of advanced ceramic parts, an assessment of powder cost is also made in combination with potential improvements in other key technical and economic paraneters of the manufacturing technology.

Our assumption that ceramic parts must not exceed the cost of metallic parts may not be valid given that some properties of ceramics parts are superior and others inferior to parts made from metallics. The economic viability of advanced ceramics will depend on the balance of marginal costs and benefits provided by ceramics and metallics. However, this simplifying assumption offers a starting point for the analysis and may, in fact, closely reflect the actual decision process in the early stages of adoption. 
Two automotive engin's parts are considered in the analysis -- i.e., roller followers and turbocharger rotors. These parts are representative of the spectrum of complexity of advanced ceramic components. Silicon nitride turbochargers are, perhaps, the most exciting and demanding engine application of advanced ceramics. Ceramics offer the benefit of low inertia, which reduces turbocharger lag. About 10,000 turbochargers per month are used in Nissan's 300ZX and other cars, all built and sold only in Japan. A high-pressure technology -- sintering in a reactive gas overpressure of nitrogen pressure (as high as 2,000 atmos. pressure) -- is used to commercially manufacture these turbocharger rotors in Japan. In the United States, with the exception of a very limited production run by Buick, ceramic turbochargers have yet to be used in any passenger car. However, ceramic turbochargers supplied by Schwitzer, Holset, Garrett, and Mitsubishi, are currently being used in diesel engines in small pickup trucks, such as those made by Dodge and Ford (F-250 \& F-350). Inconel 713C superalloy is the conventional material used for turbocharger rotors, and these metallic turbocharger rotors currently cost about $\$ 15$ to $\$ 20 /$ piece (Srinivasan, 1991).

Numerous options are currently being considered by the automotive industry to improve the reliability and efficiency of valve-train performance in four-cylinder in-line gasoline engines. Among these options are alternative designs of overhead camshafts with a simple rail-type rocker arms, including the replacement of the hardened steel wear pad on the rocker arm with a silicon nitride roller follower. Steel followers with needle bearings are currently being used in the rocker arms of most Ford engines. Mitsubishi uses sintered silicon nitride ceramic rocker arm pads in its taxicabs that are used in Japan. Other innovative options include coating the camshaft lobes with a wear resistant coating and replacing the valves with lightweight titanium alloy valves. Das and Curlee (1989) provide preliminary cost estimates of some of the options currently being considered by the industry. According to Sherman (1991), existing steel followers with needle bearings cost $\$ 0.60 /$ piece, a cost that we assume silicon nitride followers must achieve to be competitive with existing steel followers. 


\section{APPROACH}

Our basic approach is to utilize process-cost models to estimate the contribution that lower-cost silicon nitride powders could make toward reduring the costs of silicon nitride turbocharger rotors and roller followers. A base-case set of assumptions is given which is an optimistic representation of current or near-term economic and technology conditions. The costs of our representative engine parts are estimated given these base-case assumptions. These estimates are followed by an analysis of the sensitivity of base-case costs to reductions in the cost of silicon nitride powder.

Given that improvements are expected along techinical frontiers other than powder production, the contribution of lower cost powders in reducing part cost is also assessed when combined with other improvements in production technology. Our process-cost models are first used to determine the technical parameters to which production costs are most sensitive. Those technical parameters are then varied in combination with reductions in powder cost to estimate the overall impacts on part costs.

Process-cost models developed by Poggiali (1985) at the Massachusetts Institute of Technology's (MIT) Materials Systems Laboratory were used as the starting point for the models used here. In process-cost modeling, each production step involved in a particular technology is modeled individually, and the values of all the inputs associated with each process are calculated by process step and for the production process as a whole. These inputs include raw materials, energy, labor, equipment, and capital, each of which is process dependent. The output for the first process step, in terms of total cost and the costs of individual inpuis, becomes an input to the second production step, and so forth. Thus, at each production step the models can be used to estimate the total cost of the product at that step, the contribution of that production step to the total cost of the product at that point in production, and the contribution of each input to the total cost and to the cost of a particular production step. Das and Curlee (1988) used this approach in a cost estimation of ceramic tubes and headers used in advanced heat exchangers.

Isopressing and injection-molding misufacturing methods are considered for roller followers and turbocharger rotors, respectively. The sip-casting method (not considered here) is another route for manufacturing turbocharger rotors. Slip-cast parts are less dense than those produced by injection molding, and with current technology would require hot isostatic pressing to achieve final density. German et al. (1991) discuss key issues, such as powders, mixing, and dimensional integrity in powder injection molding, that need to be solved for the process to become the choice for forming existing and emerging materials into precise, high-quality components.

Extensive enhancements were made to the MIT models with respect to key technical and economic input parameters and functional relationships. Enhancements of functional relationships were similar to the ones discussed in Das, Curlee, and Whitaker (1988). Wittmer (1991) provided values for the key technical and ecoriumic input parameters of both models. Srinivasan (1991) provided an assessment of the models used in our analysis.

The MIT cutting-tool inserts model, used as the starting point for our roller-follower model, specifically considers six process steps in the following order: material preparation, isopressing, binder removal, firing (periodic and continuous), machine shop, and quality control and storage. The roller follower considered here is essentially a cylindrical tube approximately $0.5 \mathrm{in}$. long. Outer and inner diameters are assume! to be 0.7 in. and 0.3 in., respectively. Roller followers are processed by wet 
milling powders, spray drying, and dry pressing. Drying is not required, and binder removal is accomplished in a co-binder/sinter type furnace. Crowning and grinding are the most critical manufacturing steps, as the contact between the follower and the camshaft must be accurate and precise.

The MIT turbocharger rotor model was used as the starting point for our turbocharger rotor model. The process steps in the turbocharger rotor model are identical to the roller-follower model, with the exception that the isopressing process step in the former model is replaced by the injectionmolding process step in the latter model. A single machining step is considered immediately after sintering, when both flash sprue removal and final machining are done. The final rotor weight considered for this analysis is $0.62 \mathrm{lb}$; the green part weighs approximately $1 \mathrm{lb}$, assuming a binder weight of $38 \%$. This weight is equivalent to a rotor for the Garrett T-3 type turbocharger assembly used in Buick, Saab, and Volvo, which is fabricated from silicon nitride with a density of $3.2 \mathrm{gm} / \mathrm{cc}$. Continuous sintering is assumed to be done at $1700^{\circ} \mathrm{C}$ in a flowing nitrogen atmosphere. See Appendix $\mathrm{A}$ and $\mathrm{B}$ for a complete listing of the inputs used in the roller follower anci turbocharger rotor models, respectively. 


\section{MODEL RESULTS}

\subsection{Roller Followers}

\subsubsection{Base-Case Results}

Table 3.1 lists the major base-case assumptions used to estimate the cost of roller followers using the enhanced MIT cutting-tool model. Note that silicon nitride powder is assumed to cost $\$ 20 / \mathrm{lb}$ in the base case. Other assumptions reflect current or near-term state-of-the-art manufacturing processes.

Table 3.1 Base-case assumptions for roller followers

\begin{tabular}{ll}
\hline Part Weight & $0.02 \mathrm{lbs}$ \\
Powder Cost & $\$ 20 / \mathrm{b}$ \\
(includes sintering aids) & \\
Max. Production Volume & $10,000,000$ parts/year \\
Process Step Yields & \\
Materials Preparation & $99 \%$ \\
Pressing & $99 \%$ \\
Binder Removal & $98 \%$ \\
Sintering & $95 \%$ \\
Grinding & $98 \%$ \\
Inspection & $98 \%$ \\
Total Yield & $88 \%$ \\
Binder Removal Time & $8 \mathrm{hrs}$ \\
Sintering & $1700^{\circ} \mathrm{C}$ in $\mathrm{N}_{2}$ atmosphere \\
Grinding Rate & $30 \mathrm{parts} / \mathrm{hr}$ \\
Labor Cost & $\$ 13.50 / \mathrm{hr}$ \\
Total Capital Cost & $\$ 8 \mathrm{M}$ \\
(at Max. Production Volume) & $12 \%$ \\
Cost of Capital & \\
\hline
\end{tabular}

"Yield is defined as the physical yield of the process (i.e., 1 - scrap rate).

Figure 3.1 gives the estimated base-case cost and its distribution by major cost category for manufacturing roller followers using the assumed isopressing technology. The cost of labor, at $44 \%$ of total cost, is estimated to be the largest cost component, considerably higher than the cost of materials. Eighty-five percent of total labor cost occurs at the finishing step, for which a tight input tolerance is required. Materials costs are second highest and are estimated to contribute $37.1 \%$ to total costs. The costs of capital charges, other inputs, and energy follow in terms of their overall contributions to the cost of manufacturing roller followers. 

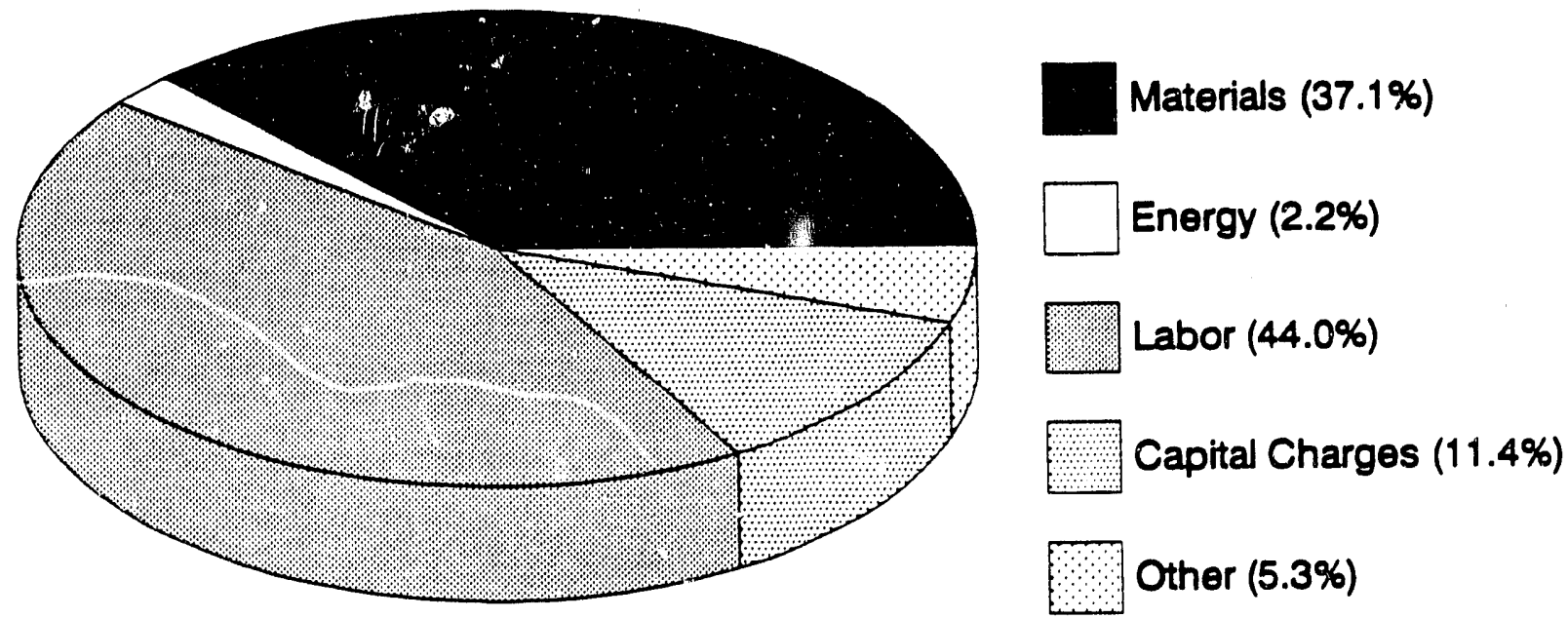

Total Cost (\$1.32/piece)

\section{Flgure 3.1 Estimated base-case cost of manufacturing sillicon nitride roller followers.}

\footnotetext{
Aceumptions: Total Yild : $87.0 \%$

Pouder Cont : saonb (Silicon Nirido Pounder = \$17.2016 with Yurum Oxide es eintaring edo) Grinding Rata : 30 piscese/hr
} 
The bast - ise cost of a roller follower is estimated to be $\$ 1.32$ per piece, as compared to $\$ 0.60$ for existing stet. followers with needle bearings. Therefore, silicon nitride roller followers are not competitive with conventional steel parts under our base-case assumption.

The sensitivity of roller follower cost to reductions in powder custs (ircluding sintering aids $\mathrm{Al}_{2} \mathrm{O}_{3}$ and $\mathrm{Y}_{2} \mathrm{O}_{3}$ or $\mathrm{La}_{2} \mathrm{O}_{3}$ ) is illustrated in Figure 3.2. Powder composition is assumed to be $85 \%$ silicon nitride, $13 \%$ yttrium or lanthanum oxide, and $2 \%$ alumina. The solid line represents total powder cost, including sintering aids. The dotted line represents the cost of silicon nitride rowder only, given that yttrium oxide is used as the sintering aid. The dashed line represents the cost of silicon nitride powder only, given that lanthanum oxide is used as the sintering aid.

For our base-case follower cost of $\$ 1.32$ per piece, total powder cost is $\$ 20 / \mathrm{b}$. For a total powder cost of $\$ 20 / \mathrm{b}$, the cost of silicon nitride powder is $\$ 22.65 / \mathrm{bb}$ if $\mathrm{La}_{2} \mathrm{O}_{3}$ is used as the sintering aid and $\$ 17.29 / \mathrm{b}$ if $\mathrm{Y}_{2} \mathrm{O}_{3}$ is used. For any given follower cost, silicon nitride powder cost is higher with the less expensive sintering aid, $\mathrm{La}_{2} \mathrm{O}_{3}(\$ 5 / \mathrm{hb})$, than with the more expensive $\mathrm{Y}_{2} \mathrm{O}_{3}(\$ 40 / \mathrm{b})$. The estimated cost of a follower increases linearly by $\$ 0.02 /$ piece with a unit increase $(\$ / \mathrm{b})$ in total powder cost. The difference in follower cost due to the use of the two different sintering aids is near constant over the cost range examined. A follower is estimated to be $\$ \mathrm{C} .10$ cheaper when $\mathrm{La}_{2} \mathrm{O}_{3}$ is used as a sintering aid as compared to $\mathrm{Y}_{2} \mathrm{O}_{3}$.

Figure 3.2 indicates that if total powder cost is reduced to $\$ 10 / \mathrm{b}$ (which reflects a $\$ 5.53 / \mathrm{b}$ cost for silicon nitride powder if $\mathrm{Y}_{2} \mathrm{O}_{3}$ is used as the sintering aid) the cost of a roller follower is estimated to be reduced to $\$ 1.11 /$ piece. This cost is almost twice the cost of existing metallic parts. Given that high-quality silicon nitride powders are unlikely to go below $\$ 5$ to $\$ 6$ per pound in the foreseeable future, the model suggests that a lower silicon powder cost will not alone be sufficient to make silicon nitride followers competitive with existing metallic counterparts.

\subsubsection{Sensitivity Analyses}

Given that cost-reducing improvements are likely along several technology fronts, our processcost model was exercised to estimate the technology parameters to which total cost is most sensitive. Sensitivity analyses were performed on several technical parameters, including total yield, annual production volume, and grinding rate. The following subsections examine how reductions in powder cost, in combination with other technology improvements that lower cost, could affect the total cost of roller followers.

\subsubsection{Total Yield vs Follower Cost}

In our process-cost models, total yield is defined as the product of the individual process yields. A uniform technical change in all individual process steps is considered by means of a "technology factor," a multiplicative factor common to all individual process step yields. Here, variations in total yield are examined by varying the technology factor. A technology factor range of 0.95 to 1.02 corresponds to a total yield range of $64.4 \%$ to $98.7 \%$.

Figure 3.3 illustrates the estimated relationship between follower cost and total yield. Follower cost varies linearly $\$ 0.01$ piece with a $1 \%$ change in total yield. Cost of a follower can be as low as $\$ 1.22$ when total yield is $98.7 \%$. 


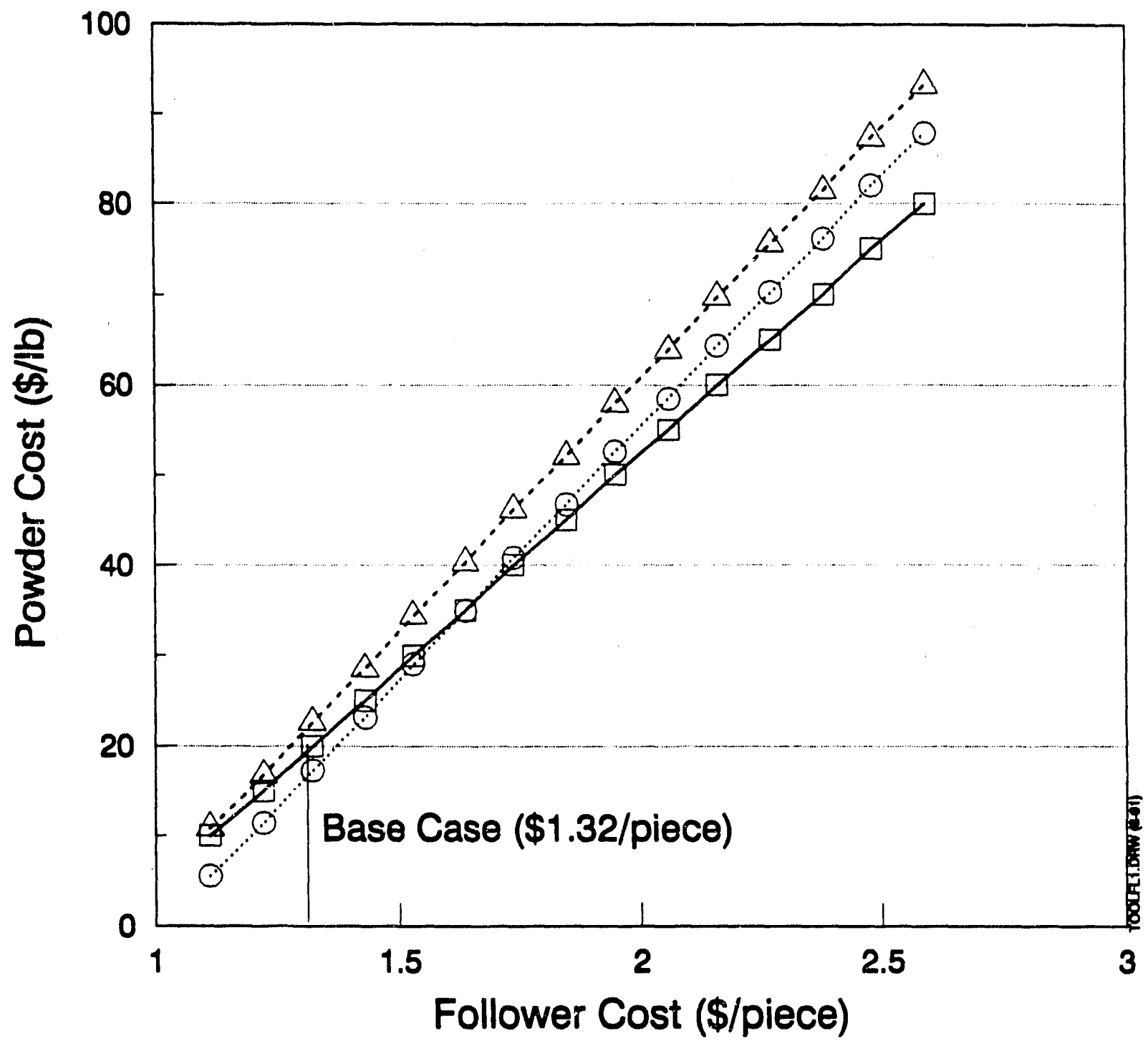

Silicon Nitride Powder Cost

(Yttrium Oxide) ….........
Silicon Nitride Powder Cost

(Lanthanum Oxide)

Total Powder Cost
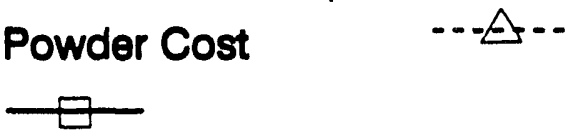

Figure 3.2 Sensitlvity of follower cost to changes in powder cost.

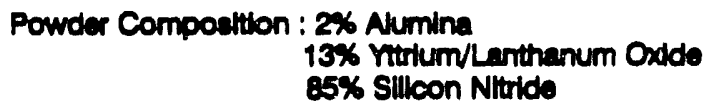




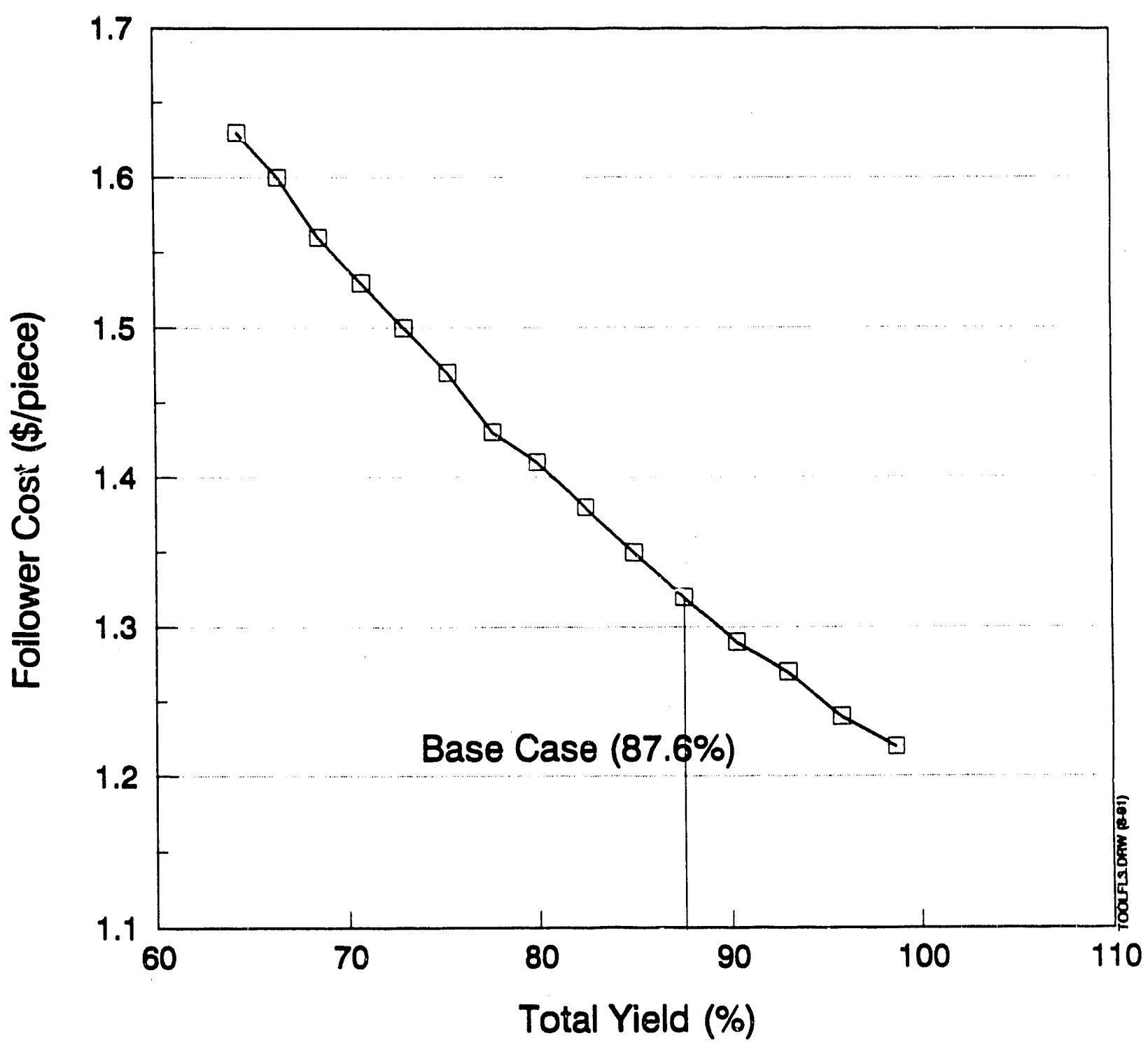

Figure 3.3 Sensitivity of follower cost to changes in total yield.

(Total yleld range of 64.4\%-98.7\% corresponds to Technology

Factor of 0.95-1.02 and Grinding Yeld of $93.1 \%-100 \%$ )

Sillcon Nitride Powder Cost $=\$ \mathbf{1 7 . 2 9 / \mathrm { b }}$ (Mtrilum Oxde sintering ald) 


\subsubsection{2 '2roduction Volume vs Follower Cost}

The sensitivity of follower cost to the yearly production volume is shown in Figure 3.4. Follower cost is sensitive to production volume, but the sensitivity decreases as production volume increases. At a low production volume of 4.4 million pieces/yr, follower cost is $\$ 1.45 /$ piece; the cost decreases by $\$ 0.05 /$ piece when the production volume increases by 1.2 million pieces/yr. Follower cost is estimated to be $\$ 1.32 /$ piece for the base-case production volume of 10 million pieces/yr.

\subsubsection{Grinding Rate vs Follower Cost}

Near-net shape processing has been advocated for some time in the advanced ceramics industry to cut down on the substantial cost incurred at final finishing. Figure 3.5 illustrates the estimated relationship between roller-follower cost and the grinding rate at final finishing and machining. Follower cost decreases sharply with an increase in grinding rate. An increase in grinding rate of 20 pieces/hr from the base-case value of 30 pieces/hr causes a decrease in base-case follower cost of $\$ 0.22 /$ piece from the base-case value of $\$ 1.32 /$ piece. A high grinding rate of 100 pieces $/ \mathrm{hr}$ can bring down the follower cost to less than one dollar (i.e., $\$ 0.94 /$ piece).

\subsubsection{Powder Cost Reductions in Combination with Other Technical Improvements}

The above sensitivity analyses indicate that production costs are most sensitive to changes in total yield and grinding rate. This subsection examines how reductions in powder cost in combination with technology improvements in these parameters that lower cost, could affect the total cost of roller followers. Figure 3.6 illustrates the sensitivity of follower cost to silicon nitride powder cost under three different assumptions about total yield. Note that the difference in follower cost between different total yields becomes larger as the cost of silicon nitride powder increases. For a given silicon nitride powder cost, say $\$ 40 / \mathrm{b}$, the cost of a follower varies between $\$ 1.60$ and $\$ 2.21$ per piece as total yield changes correspondingly between $98.7 \%$ and $64.4 \%$. Follower cost can be as low as $\$ 1.03 /$ piece if total yield is increased to $98.7 \%$ and the cost of silicon nitride powder is reduced to $\$ 5.53 / \mathrm{lb}$. Unfortunately, model results indicate that this combination of yield improvement and lower powder cost (which reflects optimistic conditions) does not reduce the cost of followers below their metallic counterparts.

The cost of roller followers was found to be highly sensitive to changes in the grinding rate at final finishing and machining. Figure 3.7 illustrates the sensitivity of follower cost to changes in the cost of silicon nitride powder under three different assumptions about the grinding rate at the finishing step. Note that for any given silicon nitride powder cost, the difference in follower cost due to different grinding rates is the same. The model suggests a reduction in follower cost of $\$ 0.38 /$ piece with an improvement in the grinding rate from the base-case rate of 30 pieces $/ \mathrm{hr}$ to 100 pieces $/ \mathrm{hr}$. Follower cost reduction is significantly higher (i.e., $\$ 0.29 /$ piece) when the grinding rate is increased from 30 pieces $/ \mathrm{hr}$ to 65 pieces $/ \mathrm{hr}$, as compared to $\$ 0.09 / \mathrm{piece}$ when the grinding rate is increased from $65 \mathrm{pieces} / \mathrm{hr}$ to $100 \mathrm{pieces} / \mathrm{hr}$. A grinding rate of $100 \mathrm{pieces} / \mathrm{hr}$ and a silicon nitride powder cost of $\$ 5.53 / \mathrm{hb}$ could yield a follower cost of as low as $\$ 0.73 /$ piece. This compares quite favorably to the $\$ 0.60 /$ piece cost of existing steel followers with needle bearings. 


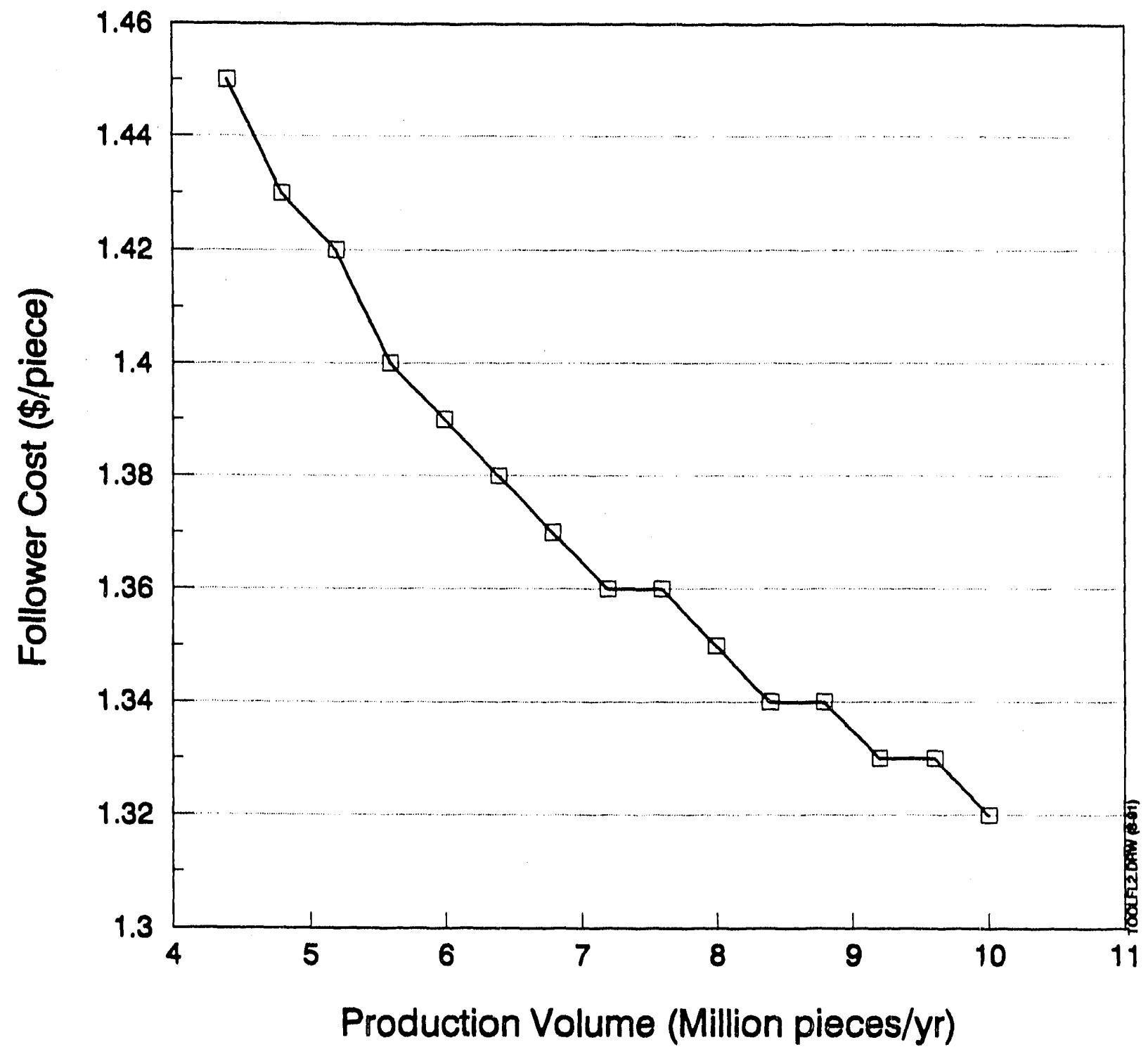

Figure 3.4 Sensitivity of follower cost to changes in production volume.

Sillcon Nituide Powder Cost $=\$ 17.29 / \mathrm{b}$

(Mtrium Oxdde sintering aid) 


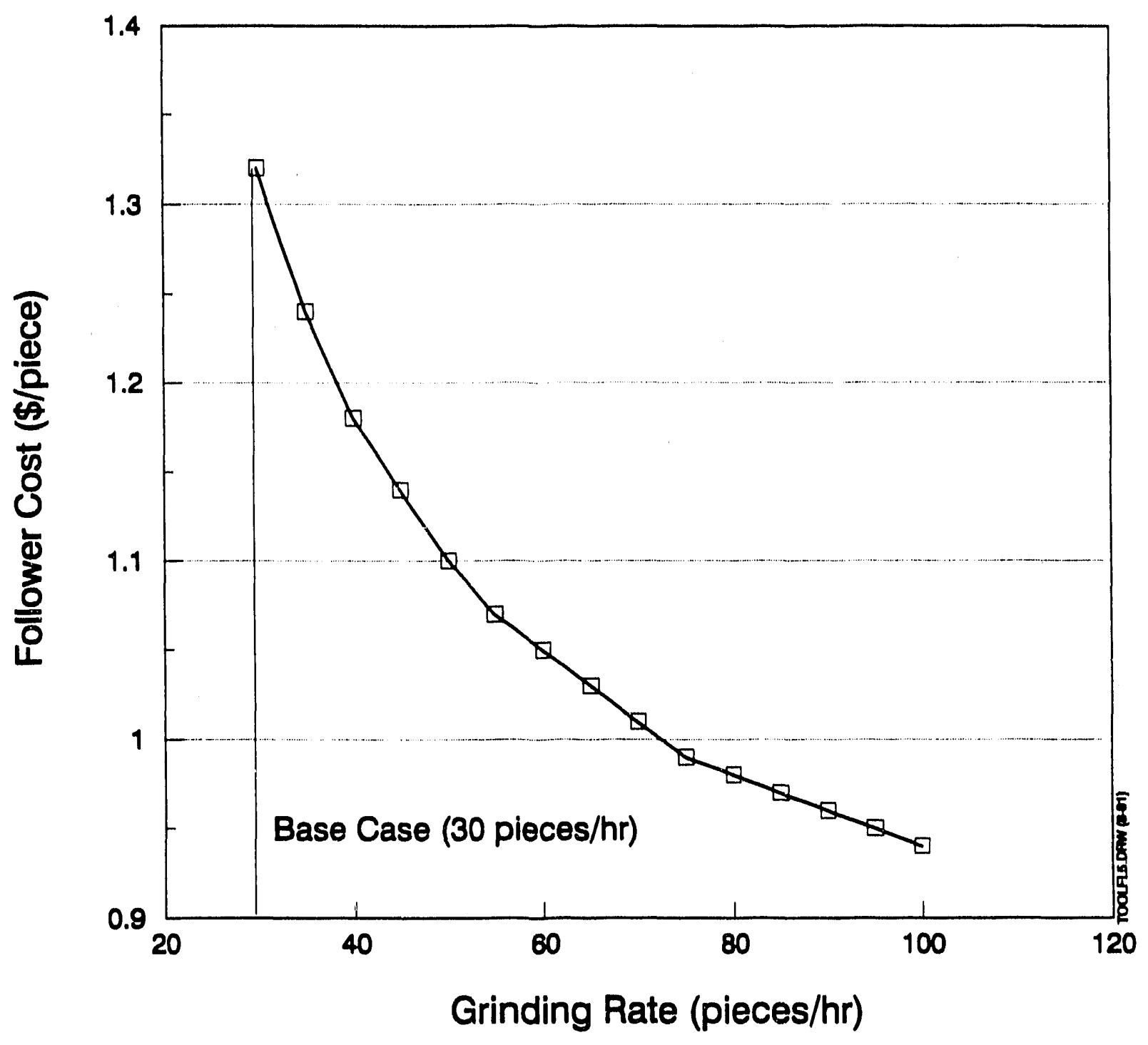

Figure 3.5 Sensitivity of follower cost to changes in grinding rate.

Silicon Nitride Pouder Cost $=\$ 17.29 / \mathrm{b}$

(Mitrium Oxide sintering aid) 


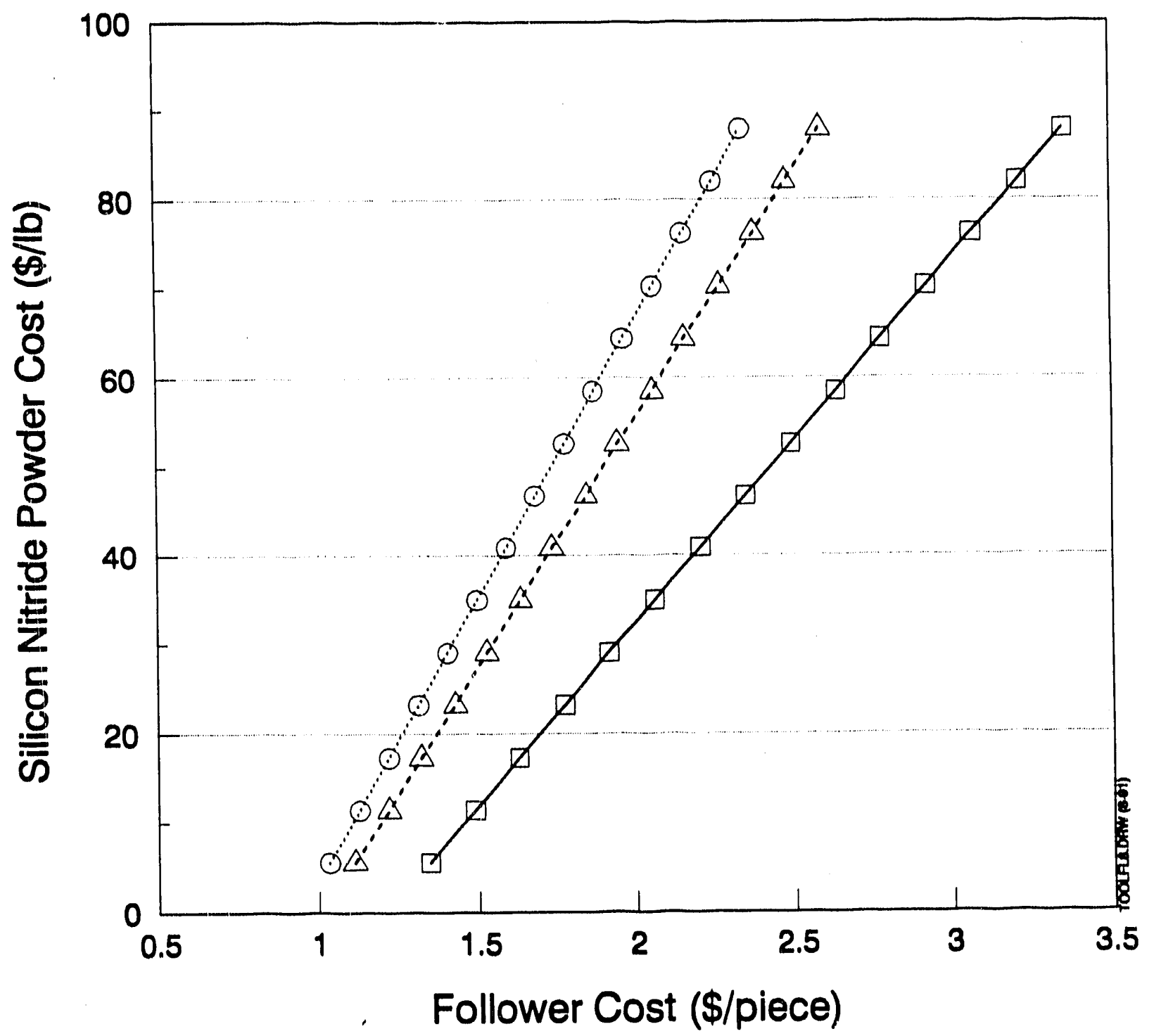

Total Yiald $=64.4 \%$

Total Yield $=87.6 \%$

Total Yield $=98.7 \%$

$-$

..-..-

….............

Figure 3.6 Sensitlvity of follower cost to changes in sillcon nitride powder cost and total yleld.

(Assumes powder compostiton : 2\% Alumina @ \$5/1b

$13 \%$ Yitria @ \$40/1b and rest 85\% Sillcon Nitride) 


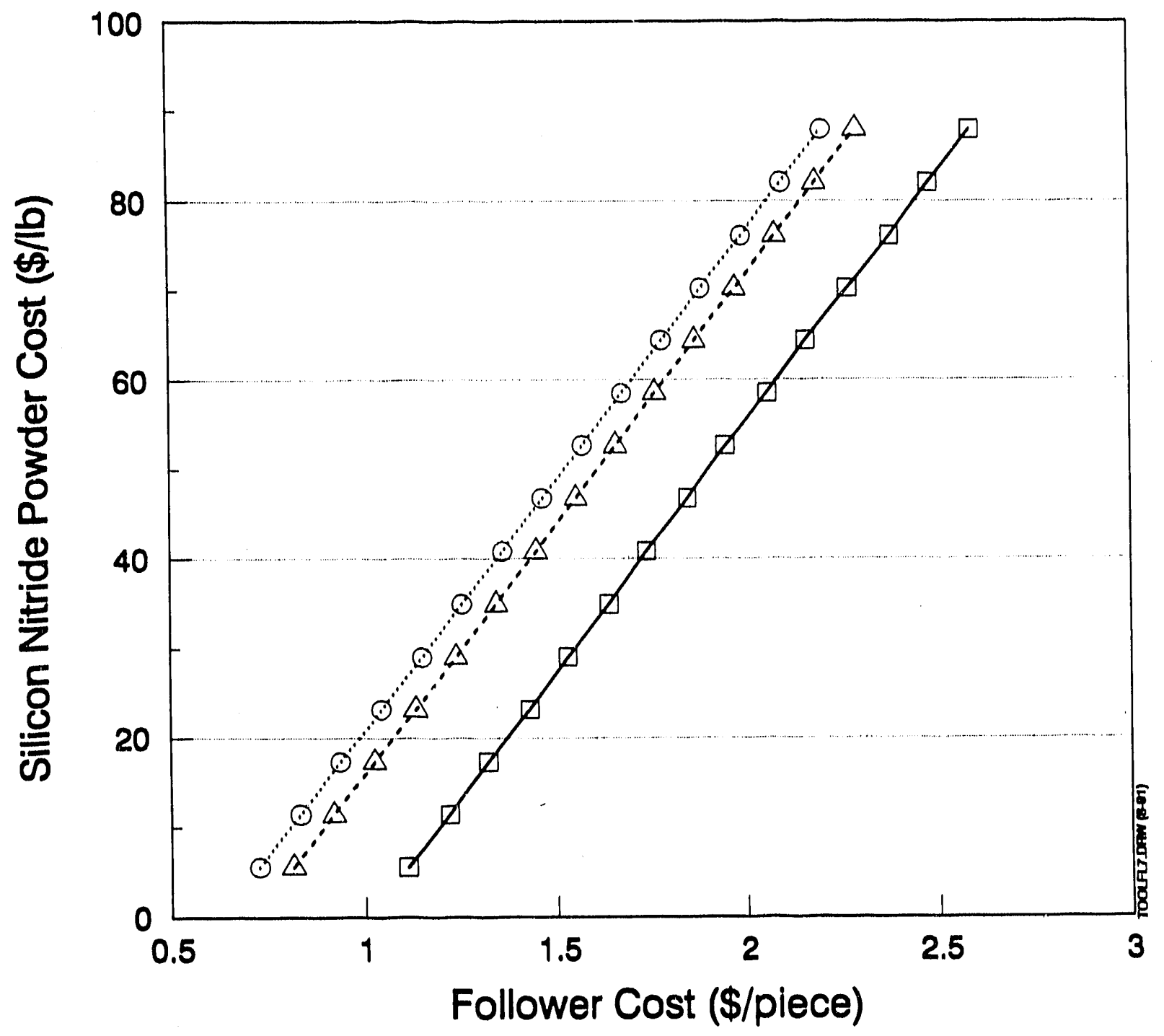

Grinding Rate ${ }^{\star}=30$

(Base Case)

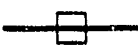

Grinding Ratê $=65$

Grinding Rate ${ }^{\star}=100$

$\cdots-\Delta-$.

(...............

Figure 3.7 Sensitivity of follower cost to changes in silicon nitride powder cost and grinding rate.

(Asoumes powder compoaltion : 2\% Alumina @ \$5/1b

13\% Yttria @ \$40/b and reot $85 \%$ Silicon Nitride)

"Grinding Rate (pleces/hr) 


\subsection{Turbocharger Rotors}

\subsubsection{Base-Case Results}

Table 3.2 lists the major base-case assumptions used to estimate the cost of turbocharger rotors using the enhanced MIT turbocharger rotor model. As in the case of roller followers, these assumptions are an optimistic reflection of current or near-term state-of-the-art technology.

Table 3.2 Base-case assurnptions for turbocharger rotors

\begin{tabular}{ll}
\hline Part Weight & $0.62 \mathrm{lbs}$ \\
Powder Cost & $\$ 20 / \mathrm{b}$ \\
(includes sintering aids) & \\
Max. Production Volume & $2,000,000$ parts/year \\
Process Step Yields & \\
Materials Preparation & $95 \%$ \\
Injection Molding & $98 \%$ \\
Binder Removal & $98 \%$ \\
Sintering & $95 \%$ \\
Grirding & $98 \%$ \\
Inspection & $98 \%$ \\
Total Yield & $83 \%$ \\
Binder Removal Time & $72 \mathrm{hrs}$ \\
Sintering & $\mathrm{Continuous} \mathrm{at} 1700^{\circ} \mathrm{C}$ in $\mathrm{N}_{2}$ \\
& atmosphere \\
Grinding Rate & $3 \mathrm{parts} / \mathrm{hr}$ \\
Labor Cost & $\$ 13.50 / \mathrm{hr}$ \\
Total Capital Cost & $\$ 112 \mathrm{M}$ \\
(at Max. Production Volume) & \\
Cost of Capital & $12 \%$ \\
\hline
\end{tabular}

"Yield is defined as the physical yield of the process (i.e., 1 - scrape rate).

Figure 3.8 gives the estimated base-case cost and its distribution by the major cost components for manufacturing silicon nitride turbocharger rotors. Materials contribute an estimated $46.1 \%$ to the total base-case cost of $\$ 38.85 /$ piece, the largest of all contributors. Recall that turbocharger rotors made from Inconel $713 \mathrm{C}$ superailoy currently cost between $\$ 15$ and $\$ 20$ per piece. The major material input other than powder that contributes to materials cost is replacement of injection molding dies. (The wear factor in these dies is high and they need frequent resurfacing). Note that, in addition to powder, materials include wax, binder, mold, grinding wheels, and inert gas. 


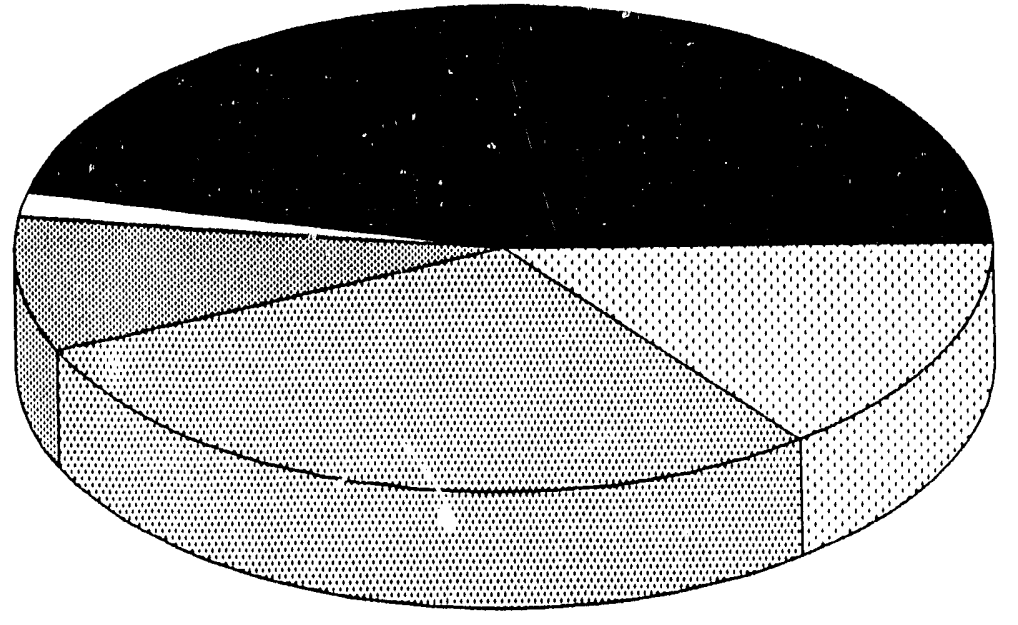

Materlals (46.1\%)

$\square$

Energy (1.6\%)

Labor' (9.0\%)

Capital Charges (28.6\%)

Other (14.7\%)

Total Cost (\$38.85/piece)

Figure 3.8 Estlmated base-case cost of manufacturing sllicon nitrlde turbocharger rotors.

Asumptions: Total Vold: $83 \%$

Powder Cont : $\$ 20 / \mathrm{hb}$ (811)con Nitride Powder $=\$ 19.02 / \mathrm{b}$

with Ytrium Oxdde as eintering ald)

Production Volume : 2 million plecesty

TUneor.1. ONW (189) 
Another major cost factor is capital. Tooling for the injection molded rotor is complex and expensive, and total capital cost for an annual production volume of 2 million rotors is estimated at $\$ 112$ million. The "other" cost component includes the high cost of rebuilding $c$ ontinuous furnaces, reçuired every six months, and for elements and thermocouples that may last only a week or two. Labor cost, although not high in terms of percentage of total cost, is significantly higher (i.e., $\$ 5.09 /$ piece) than is found in the case of roller followers.

Figure 3.9 illustrates the estimated relationship between the cost of powder and the total cost of manufacturing a ceramic turbocharger rotor. The assumed powder composition in this case is $2 \%$ $\mathrm{Al}_{2} \mathrm{O}_{3}+6 \% \mathrm{Y}_{2} \mathrm{O}_{3} / \mathrm{La}_{2} \mathrm{O}_{3}+92 \% \mathrm{Si}_{3} \mathrm{~N}_{2}$. The solid, dotted, and dashed lines are interpreted as in Figure 3.2. Turbocharger cost is estimated to vary linearly from $\$ 29.54 /$ piece to $\$ 76.09 /$ piece for an increase from $\$ 7.50 / \mathrm{lb}$ to $\$ 70 / \mathrm{b}$ in total powder cost. For any given turbocharger cost, silicon nitride powder cost must be lower when $\mathrm{Y}_{2} \mathrm{O}_{3}$ is used as a sintering aid as compared to $\mathrm{La}_{2} \mathrm{O}_{3}$. The former sintering aid is expensive $(\$ 40 / \mathrm{lb})$ compared to the cost of the latter sintering aid. For example, with a base-case turbocharger cost of $\$ 38.85 /$ piece and a total powder cost of $\$ 20 / \mathrm{b}$, the cost of silicon nitride powder is $\$ 21.30 / \mathrm{lb}$ when $\mathrm{La}_{2} \mathrm{O}_{3}$ is used as the sintering aid and is $\$ 19.02 / \mathrm{lb}$ when $\mathrm{Y}_{2} \mathrm{O}_{3}$ is used. The difference in turbocharger cost between the two different sintering aids is not sensitive to silicon nitride powder cost. For a given silicon nitride powder cost, a turbocharger costs $\$ 1.25$ more when $\mathrm{Y}_{2} \mathrm{O}_{3}$ is used as compared to $\mathrm{La}_{2} \mathrm{O}_{3}$.

Figure 3.9 indicates that a reduction in silicon nitride powder cost (using $\mathrm{Y}_{2} \mathrm{O}_{3}$ as the sintering aid) to $\$ 5.43 / \mathrm{lb}$ could bring down the cost of turbocharger rotors to $\$ 29.54 /$ piece, which is 1.5 to 2 times the cost of existing metallic parts. Therefore, our model suggests that lower powder cosi. will not alone be sufficient to bring about the economic viability of ceramic turbochargers.

\subsection{Sensitivity Analyses}

Our process-cost model was exercised to determine the technology parameters to which total cost is most sensitive. Sensitivity analysis was p rformed on several technical parameters, including production volume, total yield, capital costs, and grinding rate.

\subsubsection{Production Volume vs Turbocharger Cost}

The sensitivity of turbocharger cost to changes in production volume is summarized in Figure 3.10. At low levels of production volume the cost is very sensitive to changes in output. The cost per turbocharger decreases drastically, i.e., $\$ 98.79 /$ piece to $\$ 52.73 /$ piece, when the yearly production volume is increased from 100,000 to 600,000 . The sensitivity of cost to production volume diminishes greatly as the yearly production volume approaches our assumed maximum capacity limit of 2 million parts, which corresponds to our base-case assumption.

\subsubsection{Total Yield us Turbocharger Cost}

As discussed earlier, the variation of technology factor is used as the yardstick for the variation of total yield. A technology factor range of 0.91 to 1.02 corresponds to a total yield range of $47.3 \%$ to $93.7 \%$. Figure 3.11 illustrates the estimated relationship between total yield and turbocharger cost. Turbocharger cost decreases close to linearly ( $\$ 0.57 /$ piece) with a $1 \%$ increase in total process yield. Under the most optimistic conditions, turbocharger cost can be as low as $\$ 35.33 /$ piece when total yield is $93.7 \%$. 


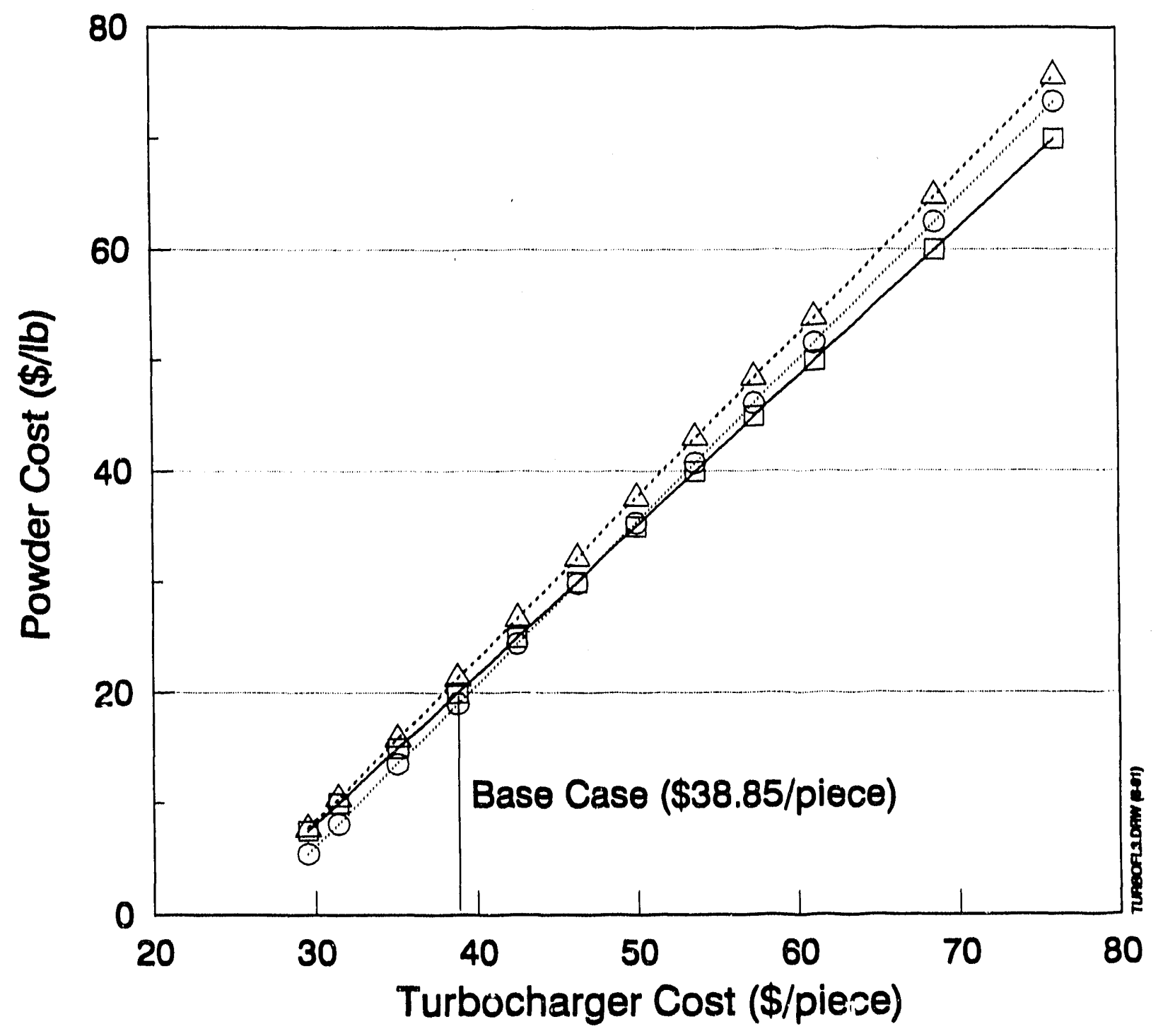

Silicon Nitride Powder Cost

(Yttrium Oxide)

Silicon Nitride Powder Cost

….........

Total Powder Cost

(Lanthanum Oxide)

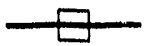

Figure 3.9 Sensitlvity of turbocharger cost to changes In powder cost.

Powder Compostition :82\% Sillcon Nituride

2\% Alumin:

O\% Vurlum/Lenthanum Oxide 


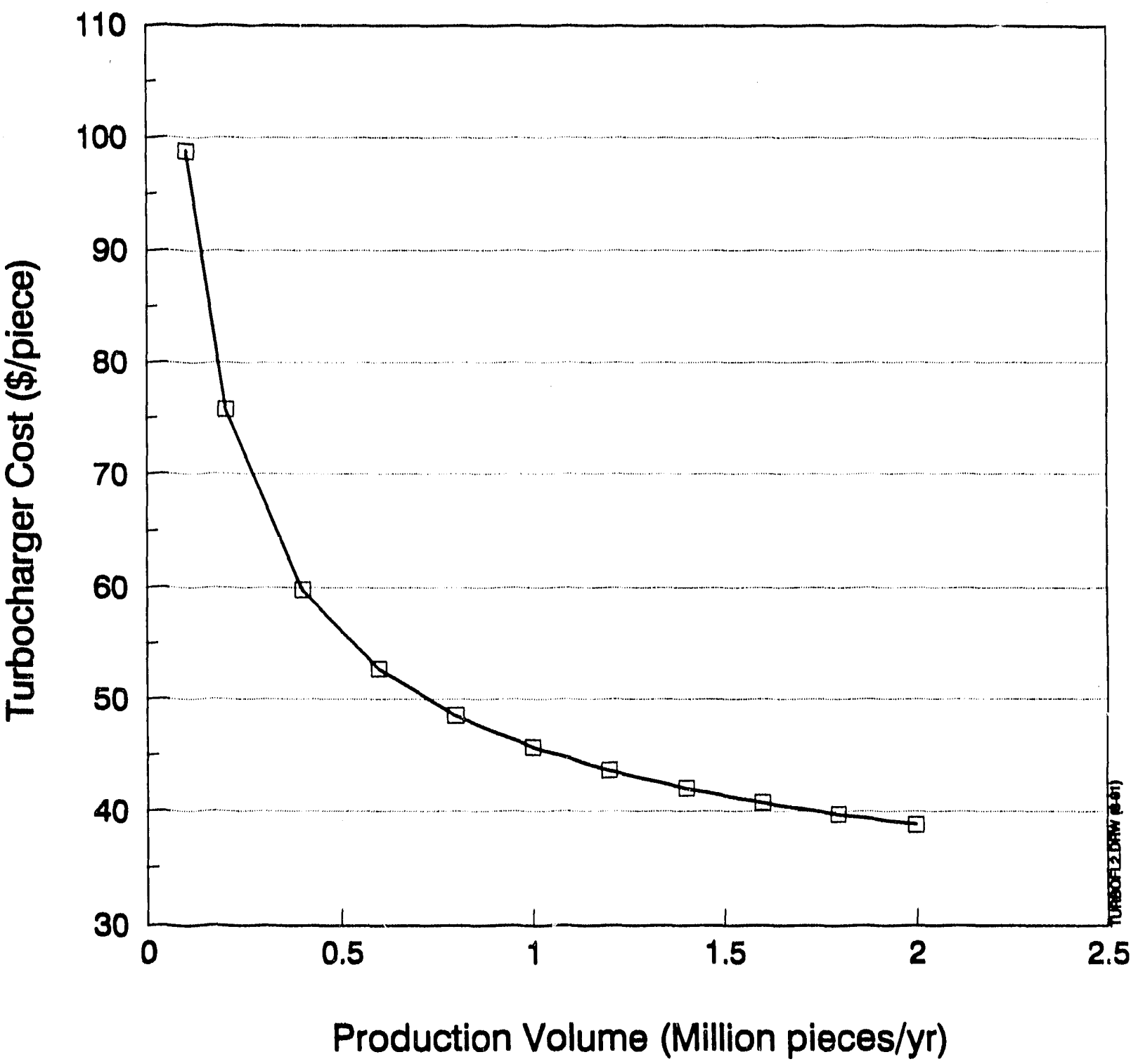

Flgure 3.10 Sensitlvlty of turbocharger cost to changes In production volume.

Silleon Nituide Powder Cost $=\$ 18.02 / 1 \mathrm{~b}$

(Mitrium Oxdde alntering ald) 


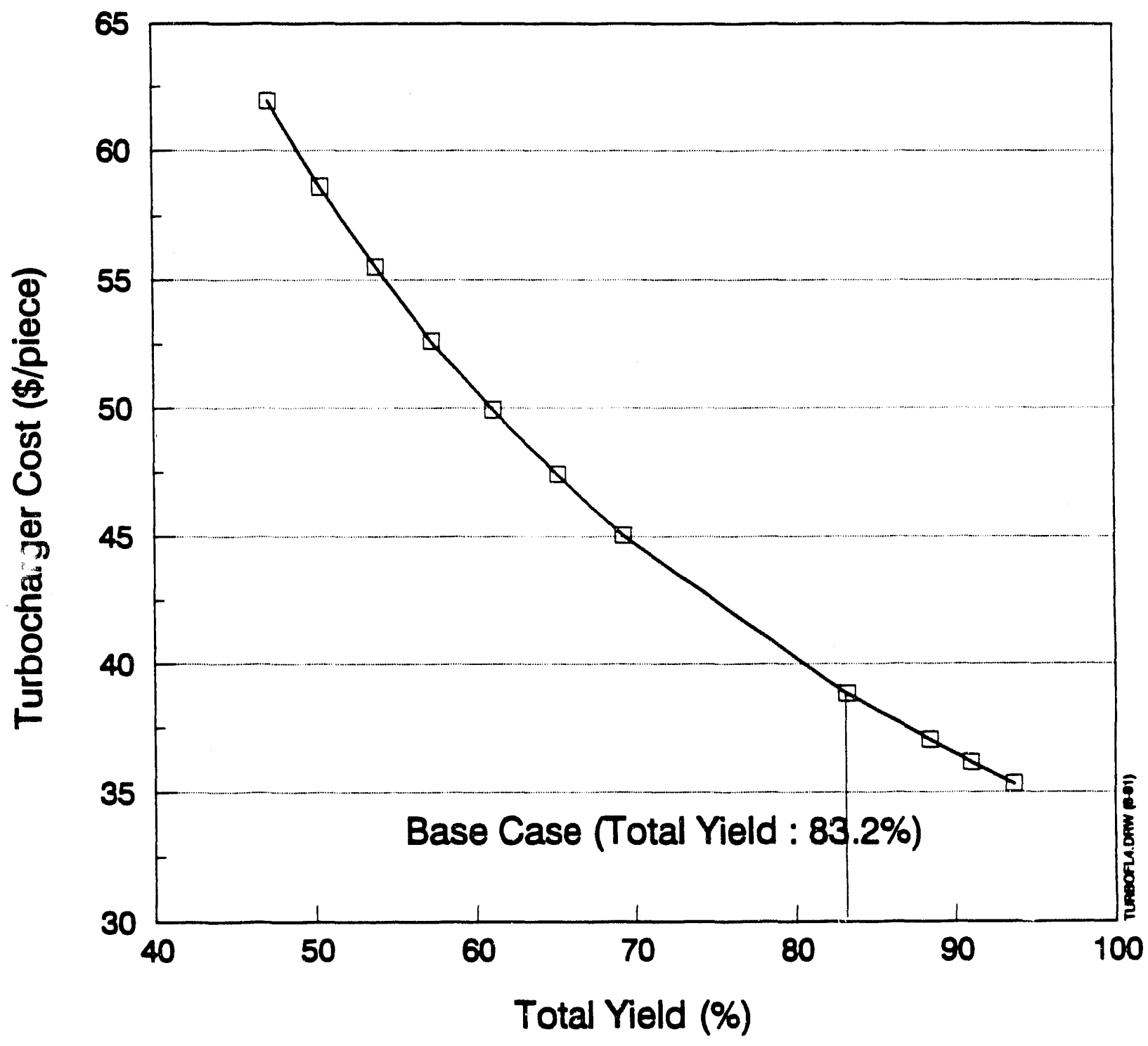

Figure 3.11 Sensitlvlty of turbocharger cost to changes in total yleld.

Total ylald range of $47.3 \%-83.7 \%$ correaponde to

Tectinology tector of 0.81 - 1.02)

sillcon Nituide Powder Cost $=\$ 18.02 / 1 \mathrm{~b}$

Murum Oxdo as intoring aid) 


\subsection{Capital Cost ws Turbocharger Cost}

The sensitivity of turbocharger cost to percentage changes in the cost of capital at various process steps is summarized in Figure 3.12. Rather than examining the sensitivity of turbocharger cost to the cost of capital at any particular step, Figure 3.12 illustrates how the estimated cost of a turbocharger changes when capital cost changes from the base-case capital cost by some given percentage. A value of 1 corresponds to the capital cost estimate used in the base case. A value of, for example, 0.8 indicates that all capital costs at all production steps equal $80 \%$ of the base-case values.

The estimated relationship between turbocharger cost and percentage changes in the cost of capital at the various process steps is linear, and the turbocharger cost increases by 17 cents/piece for every $1 \%$ increase in total capital cost. (Recall that total base-case capital cost is estimated to be $\$ 112$ million for a production volume of 2 million pieces/yr).

\subsubsection{Grinding Rate vs Turbocharger Cost}

The cost of a turbocharger is sensitive to the grinding rate per machine at the final finishing stage, as illustrated in Figure 3.13. The cost of a turbocharg 2 r decreases by $\$ 1.27 /$ piece (i.e., from $\$ 38.85 /$ piece to $\$ 37.58 /$ piece) as the grinding rate increases fro. a 3 pieces $/ \mathrm{hr}$ to 11 pieces $/ \mathrm{hr}$. The cost sensitivity is not high, since labor contributes only $9 \%$ of total cost, as observed earlier in Figure 3.8.

\subsection{Powder Cust Reductions in Combination with Other Technical Improvements}

The above sensitivity analyses indicate that production cost is most sensitive to changes in total yield and production volume. This subsection examines how reductions in powder cost, in combination with other technology improvements that lower cost, could affect the total cost of turbocharger rotors.

Figure 3.14 illustrates the sensitivity of turbocharger cost to changes in silicon nitride powder cost under three different assumptions about total yield. For a given silicon nitride powder cost of $\$ 5.43 / \mathrm{b}$, turbocharger cost is estimated to vary from $\$ 45.55 /$ piece to $\$ 27.07 /$ piece as total yield varies from $47.3 \%$ to $93.7 \%$. For higher silicon nitride powder costs, turbocharger cost variations become larger for identical variations in total yield. Under very optimistic conditions, turbocharger cost could be reduced to as low as $\$ 27.07 /$ piece if the cost of silicon nitride powder is reduced to $\$ 5.43 / \mathrm{b}$ and total yield is increased to $93.7 \%$.

The sensitivity of turbocharger cost to variations in silicon nitride powder cost for three different annual production volumes is illustrated in Figure 3.15. For a given silicon nitride powder cost, the estimated variation in turbocharger cost due to changes in yearly production volume is large (e.g., a reduction of $\$ 60.13 /$ piece when yearly production volume is increased from one hundred thousand to two million). The difference in turbocharger cost due to different production levels is unaffected by the change in silicon nitride powder cost. Our model suggests that turbocharger cost could be reduced to $\$ 29.54 /$ piece if silicon nitride powder cost is reduced to $\$ 5.43 / \mathrm{b}$ and production volume reaches 2 million pieces/yr. Production volumes below our base-case value could have a significant impact on the ultimate economic viability of silicon nitride turbocharger rotors. 


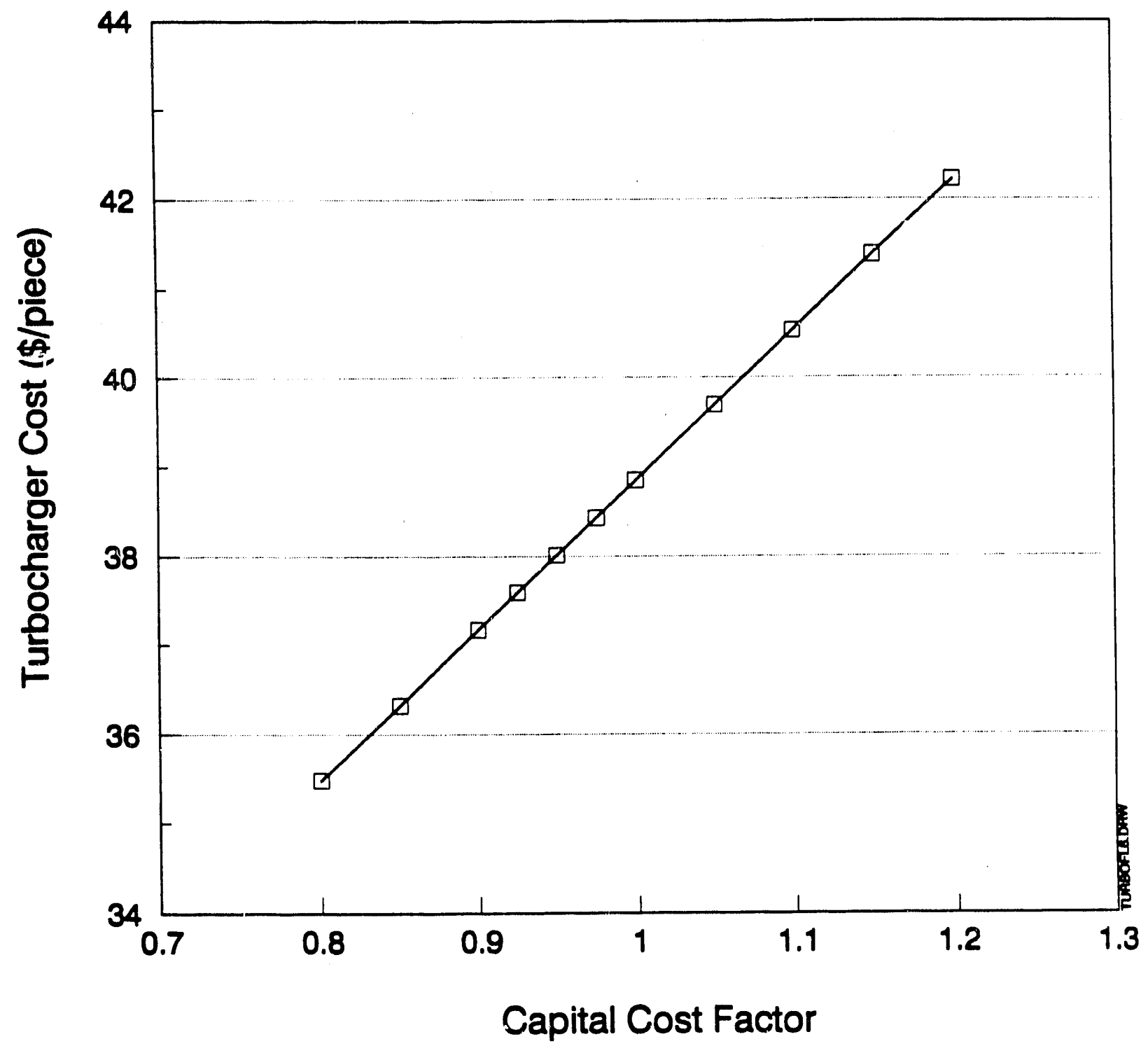

Figure 3.12 Sensitlvity of turbocharger cost to changes In capltal cost.

(A capital tector of 1 represents base case)

Base Case Total Captal Cost $=\$ 112 \mathrm{M}$

sillcon Nitulde Powder Cost $=\$ \$ 19.02 / \mathrm{b}$

(Mutum ondo so aintering aid) 


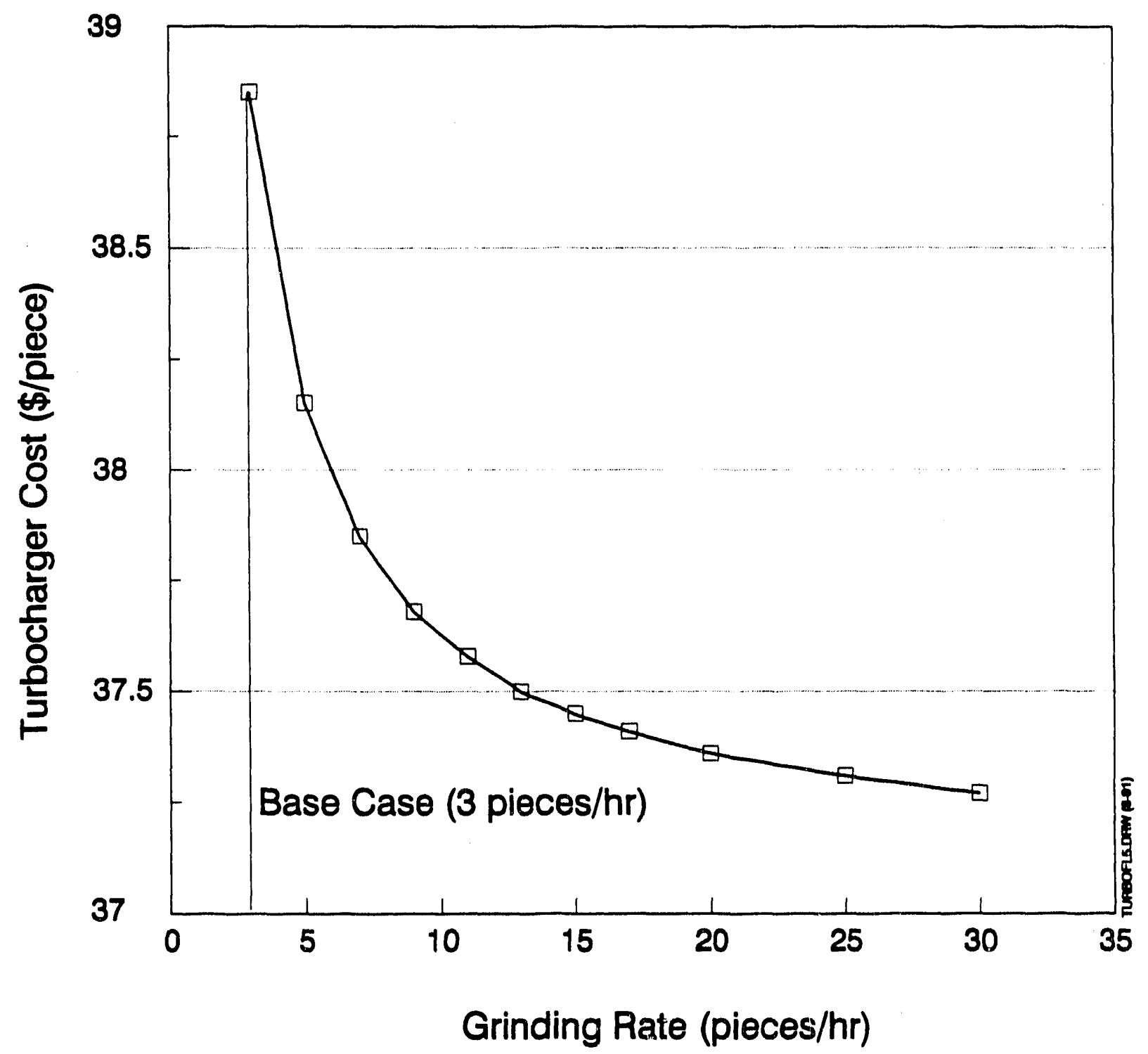

Figure 3.13 Sensitivity of turbocharger cost to changes in grinding rate. 


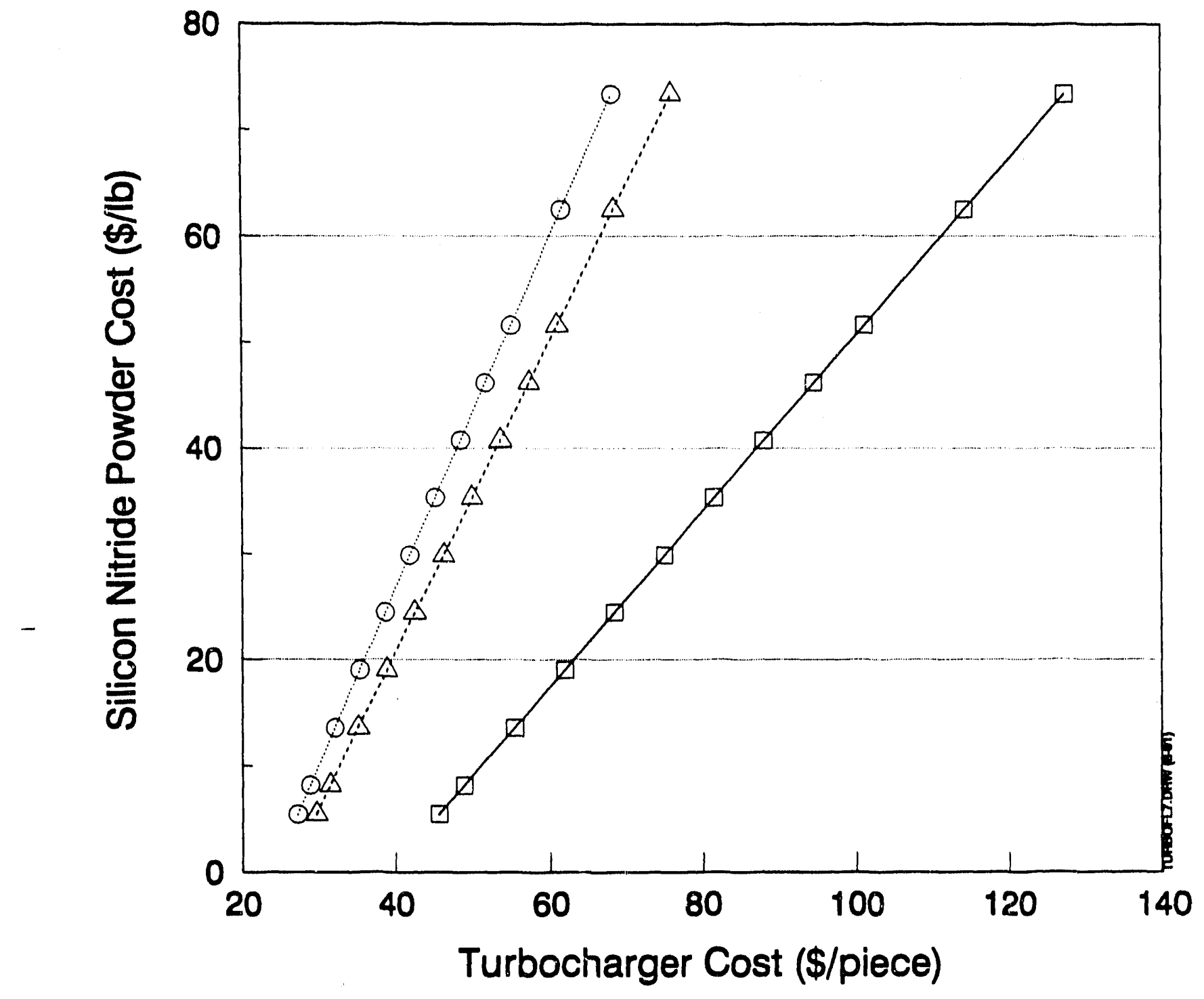
Total Yield $=47.3 \%$
Total Yield $=83.2 \%$
(Base Case)

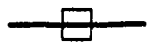
$-\cdot--\cdot$
Total Yield $=93.7 \%$
….........

Figure 3.14 Sensitivlty of turbocharger cost to changes in silicon nitride powder cost and total yleld.

(Assumes powder composition : $2 \%$ Aumina @ \$5/16

$6 \%$ Yurla @ S4O/b and reet $82 \%$ Sillcon Nitulde) 


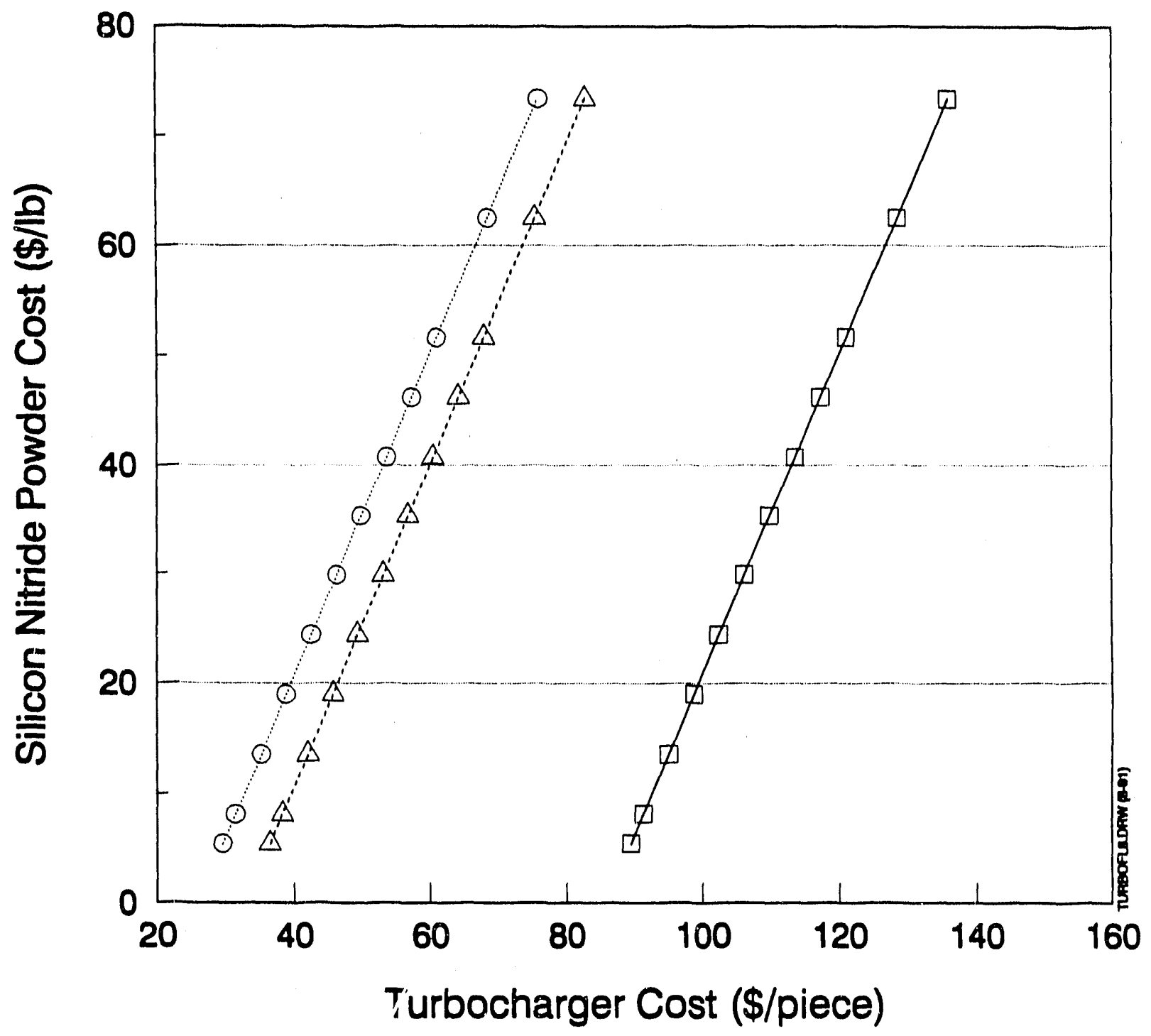
Prodn. Vol. $=1 \mathrm{~N} J \mathrm{~K}$
Prodn. Vol. $=1 \mathrm{M}$
Prodn. Vol. $=2 \mathrm{M}$
F-
-..-.
(Base Case)
(............
Figure 3.15 Sensitivity of turbocharger cost to changes in silicon nitride powder cost and production volume.




\section{CONCLUSIONS}

It is widely accepted that the cost of advanced ceramic parts must be reduced if advanced ceramics, such as silicon nitride, are to become a widespread alternative to metallics. Various R\&D programs are currently underway to reduce the cost of ceramics, including work to lower the cost of high-quality ceramic powders. High-quality silicon nitride powders currently cost about $\$ 20$ per pound, although technology improvements are envisioned that could potentially lower that cost to between $\$ 5$ and $\$ 6$ per pound.

This work focused on the potential contribution that lower cost powders could make toward improving the economic viability of advanced ceramics. The work focused specifically on silicon nitride and examined two automotive engine parts that are representative of the spectrum of advanced ceramic components -- i.e., roller followers and turbocharger rotors. The cost of an existing steel follower is about $\$ 0.60$ /piece; turbochargers cost between $\$ 15-\$ 20$ each when made from superalloys. Most industry experts argue that advanced ceramic parts must cost no more than their metallic counterparts and provide comparable quality and reliability if ceramics are to be viable alternatives to metallics.

To examine the potential contributions that lower cost powders could make in reducing the cost of ceramic components, two process-cost models were developed, one for each engine component. A base-case set of input assumptions was formulated which was judged to be an optimistic reflection of current or near-term state-of-the-art technology. The models were then used to estimate the costs of our selected engine components given these state-of-the-art conditions. Silicon nitride powder was assumed to cost $\$ 20 / \mathrm{lb}$ in the base case.

Our models suggest that under our base-case assumptions, neither roller followers nor turbocharger rotors can be produced at a cost comparable to their metallic counterparts. Roller followers are estimated to cost $\$ 1.32$ per piece (compared to $\$ 0.60$ per piece for metallics); turbocharger rotors are estimated to cost $\$ 38.85$ each (compared to $\$ 15-\$ 20$ per piece for metallics).

Sensitivity analyses revealed that reductions in the cost of silicon nitride powder from about $\$ 20 / \mathrm{lb}$ to about $\$ 5 / \mathrm{lb}$ would promote the economic viability of advanced ceramics, but would not in themselves be sufficient to lower the cost of ceramics below their metallic counterparts. Roller followers were estimated to cost $\$ 1.11 /$ piece when the cosi of silicon nitride power cost was lowered to $\$ 5.53$ per pound. Turbocharger rotors were estimated to cost $\$ 29.54 /$ piece at the lower powder cost.

The models were also exercised to estimate if reductions in powder cost, in combination with other technology improvements that lower cost, cuuld result in ceramic parts that cost less than similar metallic parts. Work was done to determine the technical parameters to which total part cost is most sensitive. In the case of roller followers, total cost was estimated to be most sensitive to total yield and grinding rate. In the case of turbocharger rotors, total cost was estimated to be most sensitive to total yield and production volume.

Although our sensitivity analyses were reflective of technical improvements that are not foreseeable at this time, the resulting part costs were still higher than similar metallic parts. Significant improvements in the grinding rate, in combination with lower cost powders, were estimated 
to reriuce the cost of roller followers to as low as $\$ 0.73 /$ piece. The cost of turbocharger rotors was reducid to as low as $\$ 27.07 /$ piece when lower cost powders were combined with significantly higher grinding rates.

Our analysis suggests that if, in fact, advanced ceramic parts must cost no more than their metallic counterparts in order for ceramics to be competitive, the current R\&D efforts to lower powder costs will not in themselves be sufficient to establish the economic viability of ceramics. Further analysis suggests that sufficient cost reductions cannot be achieved even when lower-cost powders are combined with other significant technical improvements.

These findinge call into question the notion that the cost of ceramic components must not exceed the cost of similar metallic parts. Economic viability will ultimately be decided not on the basis of which part is less costly, but on an assessment of the marginal costs and benefits provided by ceramics and metallics. This analysis did not consider the benefits side of the equation. Our findings on the cost side of the equation suggest that the competitiveness of advanced ceramics will ultimately be decided by our ability to evaluate and communicate the higher benefits that advanced ceramic parts may offer. 


\section{REFERENCES}

Das, S. and T. R. Curlee, "Ceramic Heat Exchangers: Cost Estimates Using a Process-Cost Approach," Ceramic Bulletin, 67(10):1684-89, 1988.

Das, S., T. R. Curlee, and R. A. Whitaker, Ceramic Heat Exchangers: Cost Estimates Using a Process-Cost Approach, ORNL/TM-10684, Oak Ridge National Laboratory, Oak Ridge, TN, 1988.

Das, S. and T. R. Curlee, Assessing the Costs of Competing Materials Technologies: The Example of Valve Train Components in Automobile Engines, draft report, Oak Ridge National Laboratory, 1989.

German, M. L., et al., "Key Issues in Powder Injection Molding," Ceramic Bulletin, 70(8):1294-02, 1991.

Poggiali, B., "Production Cost Modeling: A Spreadsheet Methodology," M.S. thesis in Materials Science and Technology, Massachusetts Institute of Technology, Cambridge, MA, 1985.

Rothman, E. P., Advanced Structural ceramics: Technical/Economic Process Modeling of Production and a Demand Analysis for Cutting Tools and Turbochargers, Materials Systems Laboratory, Massachusetts Institute of Technology, Cambridge, MA, 1985.

Sheppard, L. M., "Cost-Effective Manufacturing of Advanced Ceramics," Ceramic Bulletin, 70(4):692-701, 1991.

Sherman, A., Ford Motor Company Scientific Research Laboratory, Dearborn, MI, personal communication, April 2, 1991.

Srinivasan, M., An Evaluation of the Cost Inputs in the Manufacturing Model of $\mathrm{Si}_{3} \mathrm{~N}_{1}$ Turbo Rotors and Followers, Materials Solutions, Grand Island, NY, report to Oak Ridge National Laboratory, 1991.

Wittmer, D., Wittmer Consultants, Inc., Carbondale, IL, personal communication, Marci 25 and 28, April 1 and 3, 1991. 
THE COST OF SIICON NITRIDE POWDER:

WHAT MUST IT BE TO COMPETE?

\section{APPENDIX A \\ MODEL ASSUMPTIONS AND INPUT PARAMETERS}

FOR THE ROLLER FOLLOWER MODEL 
A

SILICON NITRIDE FOLIOWER FABRICATION MODEI

FACTOR PRICES

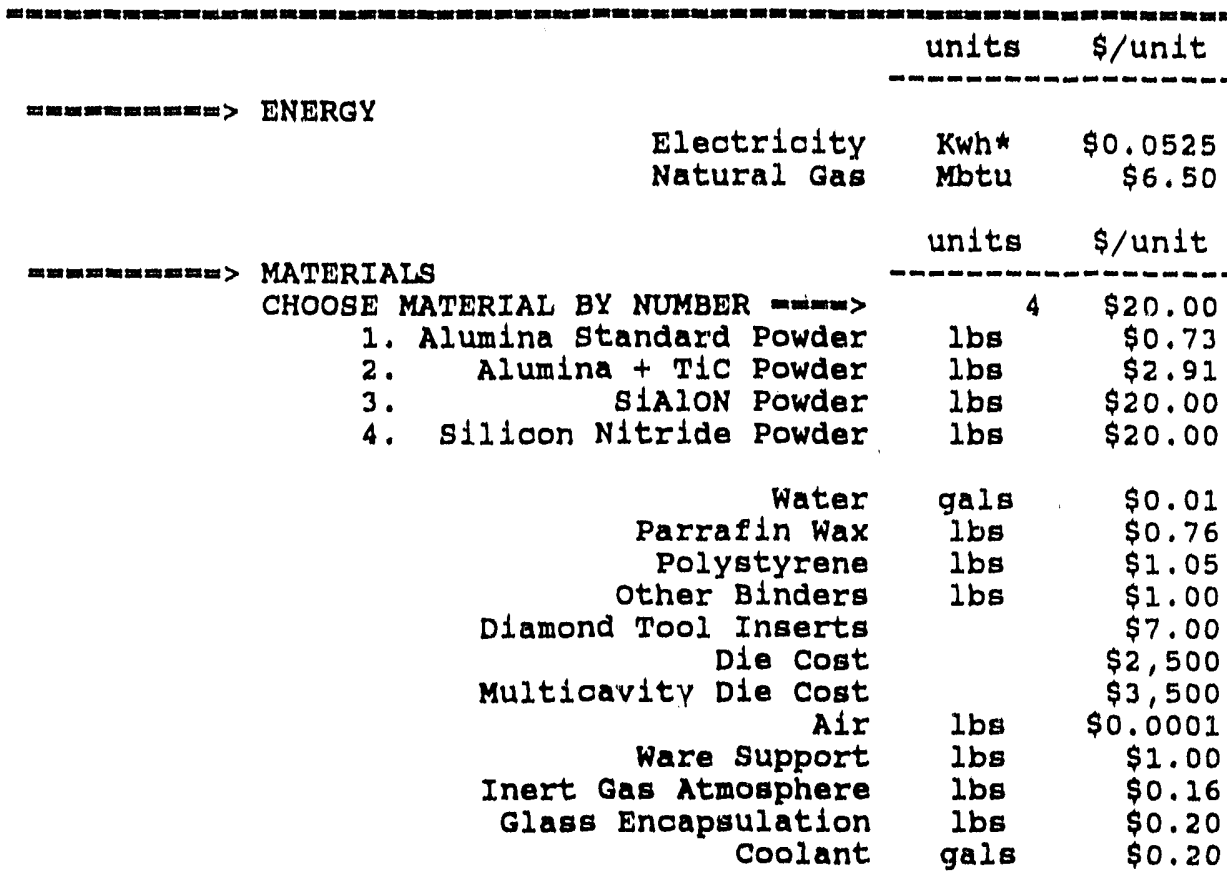

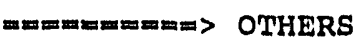

Labor (\$/man-hour) Labor Machining ( $\$$ /man-hour) cost of Capital ( of initial investment) Tax Burden (t of physical plant) Insuranoe (t of physioal plant) Maintenance (t of physioal plant) Years to Recover Investment

SENSITIVITY MULTIPLIERS Equipment scaling Factor

$\$ 13.50$

$\$ 50.00$

12.08

1.28

1.08

6.08 10

0.5

INPUT FACTORS

Plant Capacity (pieces/yr)

Max. Plant capacity (pieces/yr) Part Weight percent Binder Part Outer Diameter Part Inner Diameter Part Volume + 20 f For Shrlnkage part Length Operating Time Time Ocoupied Mixing Mixing Time
10000000 10000000

$16 \mathrm{bs}$

in

0.02

in

in

in

days/yr

hr/shft

$\mathrm{lb} / \mathrm{hr}$

hr
0.7

0.3

0.188

0.5 250 8
15

2 
A

Volume of Pressed Parts Iathe (hand operated)

Lathe CNC (tooled) Press Volume Inspection

Pressing Tool Life Tool Life Grinding Insert Iife Die Life

\begin{abstract}
B
parts/hr

parts/hr

parts/hr

parts/hr

parts/hr
\end{abstract}
pleces
pleces
hrs

parts c

1902

12

30.0

380

60

100000

1250

100000

ASSUMED PROCESS YIELDS

Note: Ist column values indicate overall yields till that process step

Material Preparation

88 \%

998 pressing

** Not Used ** Green Maohining Binder Removal Sintering Grinding Inspection Total xield INPUT Teahnology Yield Factor

Note: IInd column values indicate ylelds at the individual BINDER REMOVAL PARAMETERS

$$
\begin{array}{r}
\text { Batoh Welght } \\
\text { Welght of Ware Support } \\
\text { Green Density } \\
\text { Specific Heat }
\end{array}
$$
Binder Volume $(z)$

Relative Humidity Entrance

Entrance Air Temperature Exit Air Temperature Drying Heat Efficlenoy Binder Removal Time

CHOOSE FIRING METHOD mचm 1. Periodic 2. Continuous

* Not Used 3. HIP

* * Not Used 4.sinter/HIP * Not Used 5. Microwave $(2,45 \mathrm{GHZ}$ on $=0)$

$\begin{array}{cr}\text { Ibs/day } & 739 \\ 1 \text { bs } & 370 \\ g m / 0 c & 1.99 \\ & 0.25\end{array}$

C 200

C 25

hrs

2

39

370

25

$6 \%$

25

$80 \%$

2

$898 \quad 100 \%$

$898 \quad 98 \%$

$91 \%-95 \%$

$968 \quad 98 \%$

988

$88 \%$ 1

process step

1

FIRING PARANETERS

Thiokness of Insulation Time at Temp

Firing Temperature

Amblent Temperature

Firing Heat Efficlency (Tunnel)

Firing Heat Efficiency (Periodic) Firing Heat Efficlency (HIP)

Firing Heat Efficiency (Mloro Wave) HIPPING PARAMETERS

CHOOSE TEMPERATURE BY NUMBER $\Rightarrow$

1. Temperature (C)

2. Temperature (C)

3. Temperature (C)

0.75

2.4

3452

81

$60 \%$

$40 \%$

608

808

2

48

38

$4 \%$

HIP VESSEL DIMENSIONS 
A

119

121

122

123

124

125

126

127

128

129

130

131

132

133

134

135

136

137

138

139

140

141

142

143

144

145

146

147

148

149

150

151

152

153

154

155

156

157

158

159

160

161

162

163

164

165

166

167

168

169

170

171

172

173

174

175

176

177

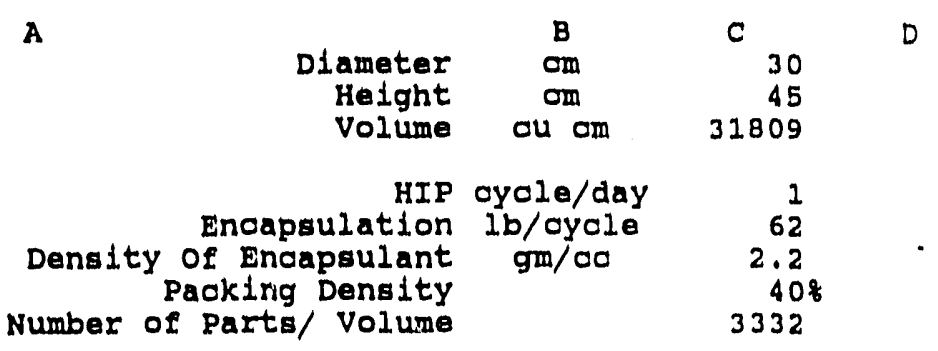

MACHINING COST AS A FUNCTION OF MATERIAL REMOVED

(This works for tolerance and near net shape) INPUT TOIERANCE HERE (*) $=m= \pm=$ ?

3

08

$\begin{array}{lccr} & & & \text { increas } \\ & \text { in } & \text { mm } & \text { 8 } \\ \text { 1. } & 0.020 & 0.508 & 0 \\ \text { 2. } & 0.010 & 0.254 & 0 \\ \text { 3. } & 0.005 & 0.127 & 0 \\ \text { 4. } & 0.002 & 0.051 & 0 \\ \text { 5. } & 0.001 & 0.025 & 10 \\ \text { 6. } & 0.000 & 0.013 & 20\end{array}$

A

B

C

D 


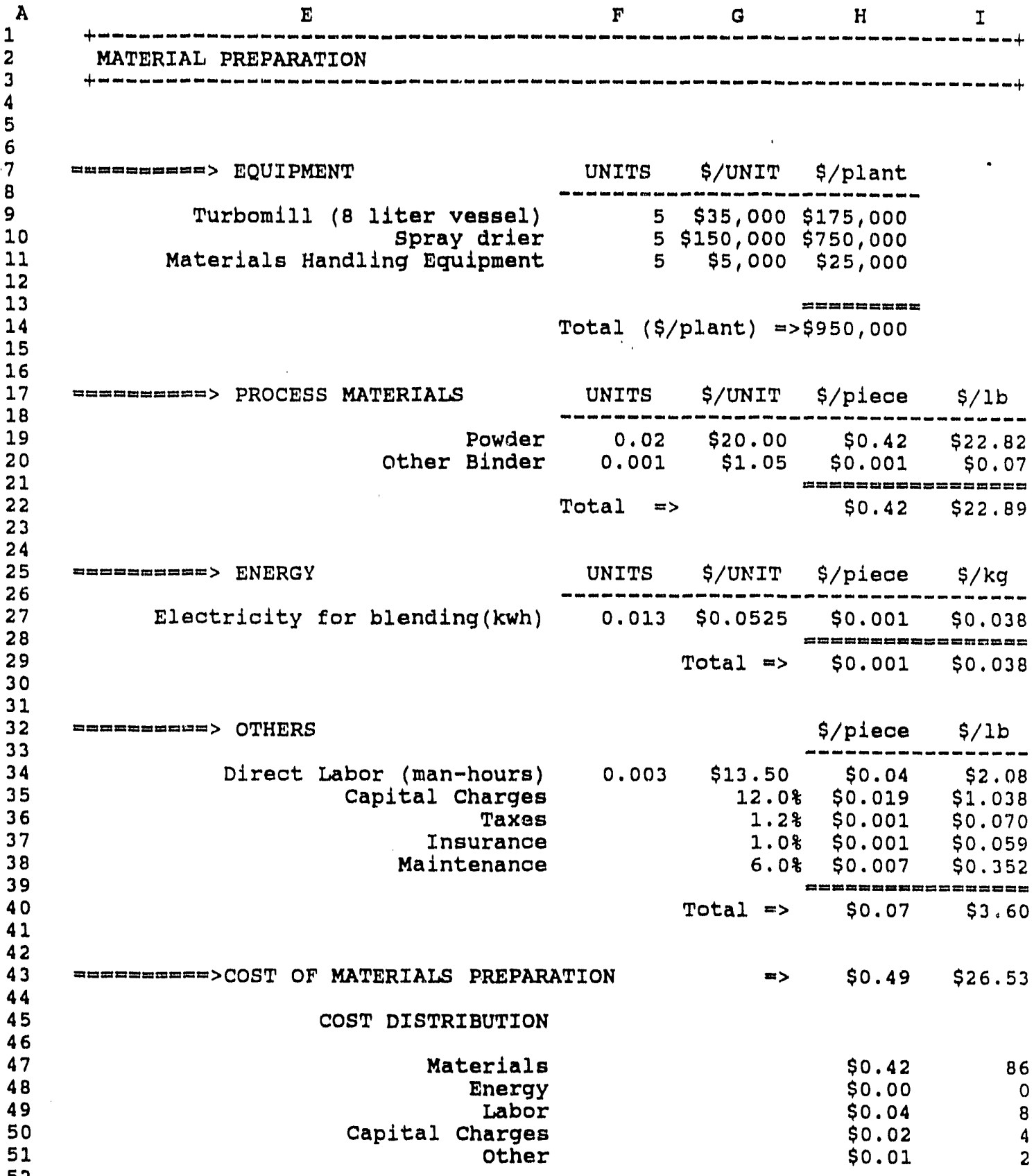

ou. cm 
A Pumping Equipment ibs/hr Materials Handling Equipment

$m== \pm=====>$ PROCESS MATERIAIS

Prepared Powder Mold Cost

$======>$ ENERGY

Electricity for pressing(kwh)

$=====>$ OTHERS

Direct Labor (man-hours) Capital Charges Taxes

Insurance Maintenance

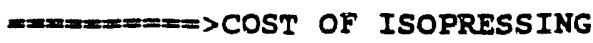

$=>C O S T$ AFIER ISOPRESSING

COST DISTRIBUTION

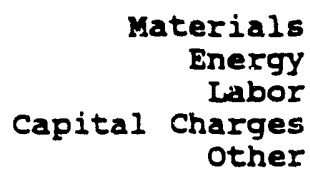

$\mathbf{K}$

I

M

I

ISOPRESSING

UNITS \$/UNIT \$/plant

$5 \$ 400,0002.00 E+06$

$\$ 9,000 \$ \$ 5,000$

$1 \$ 15,000 \$ 15,000$

Total $(\$ /$ plant $) \Rightarrow 2.06 E+06$

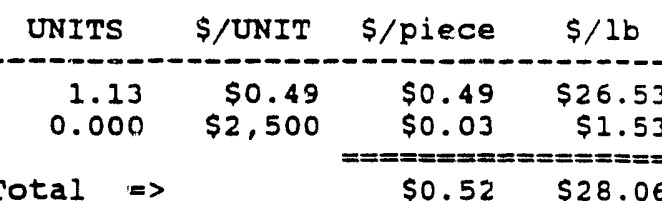

UNITS \$/UNIT \$/piece \$/lb

$0.003 \$ 0.0525 \$ 0.000 \quad \$ 0.007$

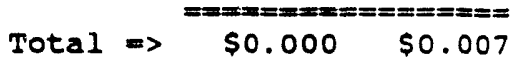

$0.0002 \$ 13.50 \quad \$ 0.003 \quad \$ 0.17$

$12.0 \% \$ 0.041 \quad \$ 2.23$

$1.28 \$ 0.003 \quad \$ 0.15$

$1.08 \$ 0.002 \quad \$ 0.13$

$6.08 \$ 0.014 \quad \$ 0.76$

Total $\Rightarrow \begin{array}{rr}==-10== \\ \$ 0.06 & \$ 3.43\end{array}$

$\Rightarrow \quad \$ 0.09 \quad \$ 4.97$

$\Rightarrow \quad \$ 0.58 \quad \$ 31.50$

$\$ 0.45$

$\$ 0.00$

$\$ 0.04$

$\$ 0.06$

$\$ 0.03$ 


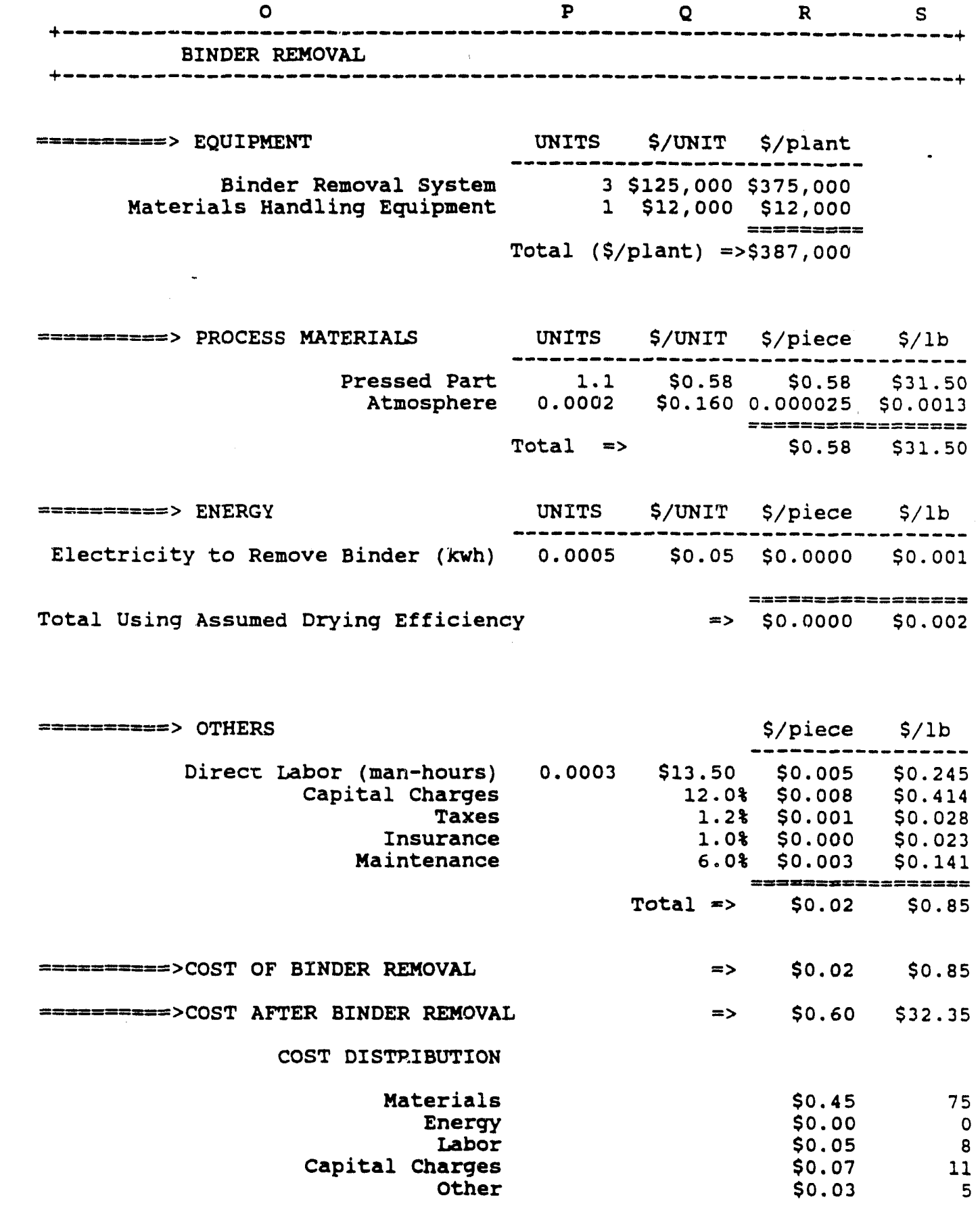


A

3$$
7
$$

Note: A value of "zero" for ( $\$ /$ plant) indicates process not being used.

$=========>$ PROCESS MATERIAIS

Part After Drying Inert Gas Atmosphere

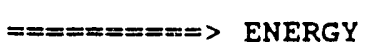

Total Using Assumed Firing Efficiency

$==\pi== \pm==>$ OTHERS

Direct Labor (man-hours) capital charges

Taxes

Insurance

Maintenance

$====x=m===>$ COST OF FIRING

$==2=2=2=1=>$ COST AFTER FIRING

COST DISTRIBUTION

Materials

Energy

Labor

capital Charges other

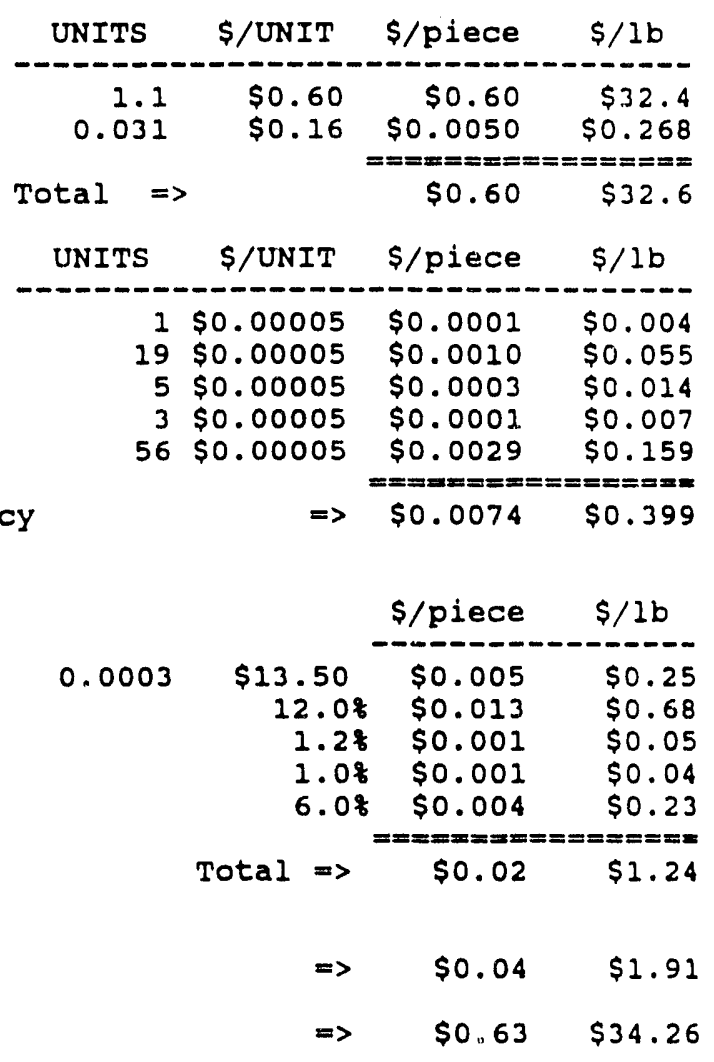

$\$ 0.46$

$\$ 0.01$

$\$ 0.05$

$\$ 0.08$

$\$ 0.04$
72
1
8
13
6 


\begin{tabular}{|c|c|c|c|c|c|}
\hline A & $Y$ & $\mathbf{z}$ & $A A$ & $A B$ & $A C$ \\
\hline & FIRING - PERIODIC KILN & r firin & g option & and 4 , ori & $1 y$ \\
\hline & & & & & \\
\hline 6 & $=========\Rightarrow$ EQUIPMENT & UNITS & $\$ /$ UNIT & $\$ /$ plant & \\
\hline $\begin{array}{l}8 \\
9 \\
10\end{array}$ & $\begin{array}{c}\text { Periodic Kiln } \\
\text { Materials Handling Equipment }\end{array}$ & $\begin{array}{l}5 \\
1\end{array}$ & $\begin{array}{r}\$ 250,000 \\
\$ 12,000\end{array}$ & $\begin{array}{r}0.00 E+00 \\
\$ 0 \\
======== \pm\end{array}$ & \\
\hline $\begin{array}{l}11 \\
12\end{array}$ & & otal (\$/ & plant $)=>0$ & $0.00 \mathrm{E}+00$ & \\
\hline $\begin{array}{l}13 \\
14\end{array}$ & Note: A value of "zero" for ( $\$ /$ plant) & & es process & $s$ not being & used. \\
\hline 15 & $========m=>$ PROCESS MATERIALS & UNITS & \$/UNIT & $\$ /$ piece & $\$ / 1 b$ \\
\hline $\begin{array}{l}17 \\
18 \\
19\end{array}$ & $\begin{array}{l}\text { Part After Drying } \\
\text { Inert Gas Atmosphere }\end{array}$ & 0.0310 & $\begin{array}{l}\$ 0.60 \\
\$ 0.16\end{array}$ & $\begin{aligned} & \$ 0.00 \\
& \$ 0.0000 \\
&==========\end{aligned}$ & $\begin{array}{r}\$ 0.00 \\
\$ 0.000 \\
===== \pm\end{array}$ \\
\hline $\begin{array}{l}20 \\
21\end{array}$ & & otal $\Rightarrow$ & & $\$ 0.00$ & $\$ 0.0$ \\
\hline 22 & $=========\Rightarrow$ ENERGY & UNITS & \$/UNIT & $\$ /$ piece & $\$ / 1 b$ \\
\hline $\begin{array}{l}24 \\
25 \\
26 \\
27 \\
28 \\
29\end{array}$ & $\begin{array}{r}\text { Energy To Heat Insulation (Whr) } \\
\text { To Evaporate Remaining Binder (Whr) } \\
\text { To Heat Part (Whr) } \\
\text { To Heat Batch Support (Whr) } \\
\text { Soaking Heat (Whr) }\end{array}$ & $\begin{array}{r}1 \\
19 \\
5 \\
3 \\
56\end{array}$ & $\begin{array}{l}\$ 0.00005 \\
\$ 0.00005 \\
\$ 0.00005 \\
\$ 0.00005 \\
\$ 0.00005\end{array}$ & $\begin{array}{l}\$ 0.0000 \\
\$ 0.0000 \\
\$ 0.0000 \\
\$ 0.0000 \\
\$ 0.0000 \\
\$========\end{array}$ & $\begin{array}{l}\$ 0.000 \\
\$ 0.000 \\
\$ 0.000 \\
\$ 0.000 \\
\$ 0.000 \\
=======\end{array}$ \\
\hline $\begin{array}{l}30 \\
31 \\
32\end{array}$ & Total Using Assumed Firing Efficiency & & $\Rightarrow$ & $\$ 0.000$ & $\$ 0.000$ \\
\hline $\begin{array}{l}33 \\
34\end{array}$ & $=========\Rightarrow$ OTHERS & & & $\$ /$ piece & $\$ / 1 b$ \\
\hline $\begin{array}{l}35 \\
36 \\
37 \\
38 \\
39 \\
40\end{array}$ & $\begin{array}{r}\text { Direct Labor (man-hours) } \\
\text { Capital Charges } \\
\text { Taxes } \\
\text { Insurance } \\
\text { Maintenance }\end{array}$ & 0.0003 & $\begin{array}{r}\$ 13.50 \\
12.08 \\
1.28 \\
1.08 \\
6.08\end{array}$ & $\begin{array}{l}\$ 0.000 \\
\$ 0.000 \\
\$ 0.000 \\
\$ 0.000 \\
\$ 0.000 \\
\$========\end{array}$ & $\begin{array}{r}\$ 0.000 \\
\$ 0.00 \\
\$ 0.000 \\
\$ 0.000 \\
\$ 0.00 \\
======\end{array}$ \\
\hline $\begin{array}{l}41 \\
42 \\
43\end{array}$ & & & Total $\Rightarrow$ & $\$ 0.00$ & $\$ 0.00$ \\
\hline $\begin{array}{l}44 \\
45\end{array}$ & $=========\Rightarrow \operatorname{COST}$ OF FIRING & & $\Rightarrow$ & $\$ 0.00$ & $\$ 0.00$ \\
\hline $\begin{array}{l}46 \\
47 \\
48 \\
49\end{array}$ & $\begin{aligned}==========>\text { COST AFTER FIRING } \\
\text { COST DISTRIBUTION }\end{aligned}$ & & $\Rightarrow$ & $\$ 0.00$ & $\$ 0.0$ \\
\hline $\begin{array}{l}50 \\
51 \\
52 \\
53 \\
54\end{array}$ & $\begin{array}{r}\text { Materials } \\
\text { Energy } \\
\text { Labor } \\
\text { Capital Charges } \\
\text { Other }\end{array}$ & & & $\begin{array}{l}\$ 0.00 \\
\$ 0.00 \\
\$ 0.00 \\
\$ 0.00 \\
\$ 0.00\end{array}$ & $\begin{array}{l}0 \\
0 \\
0 \\
0 \\
0\end{array}$ \\
\hline
\end{tabular}




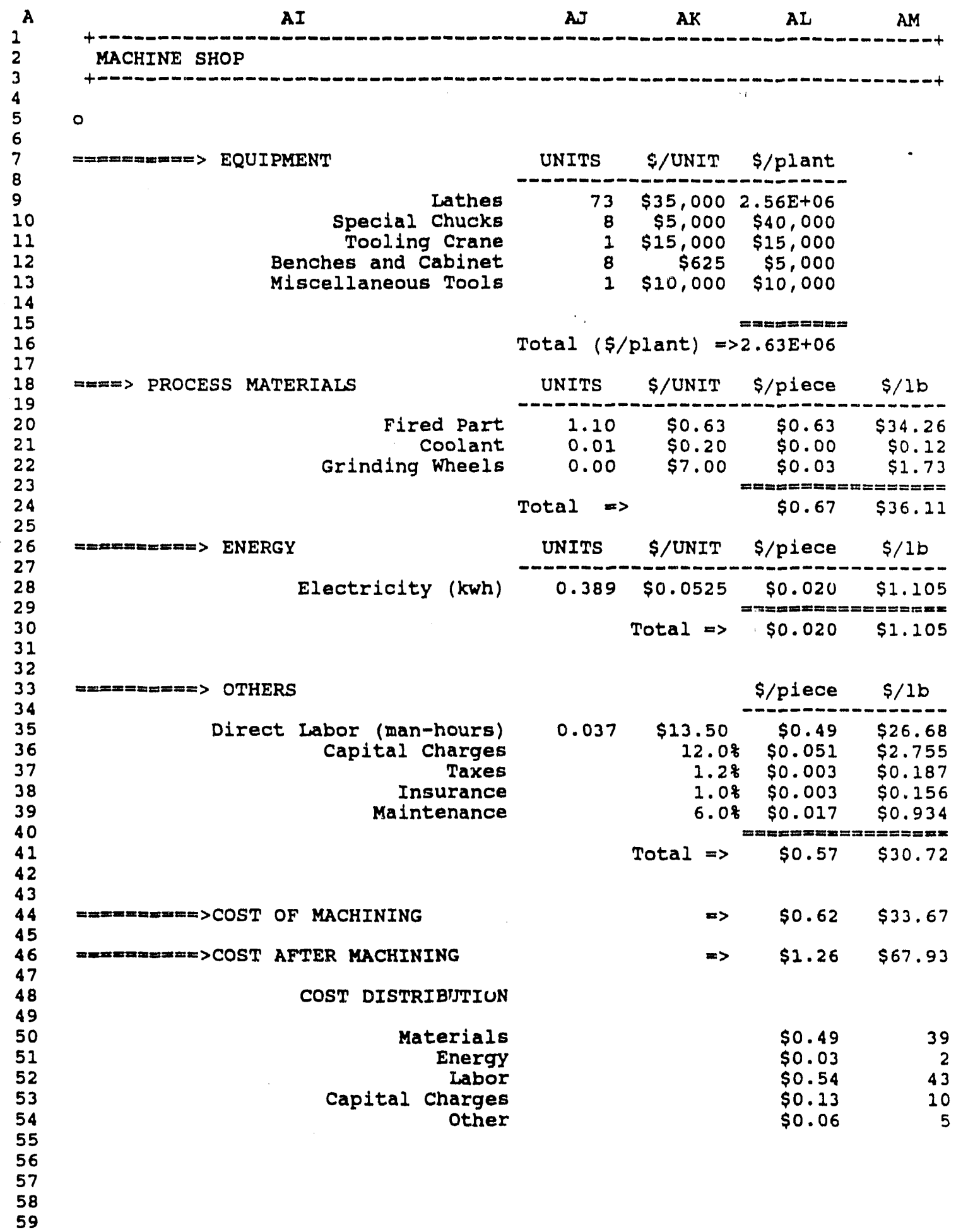




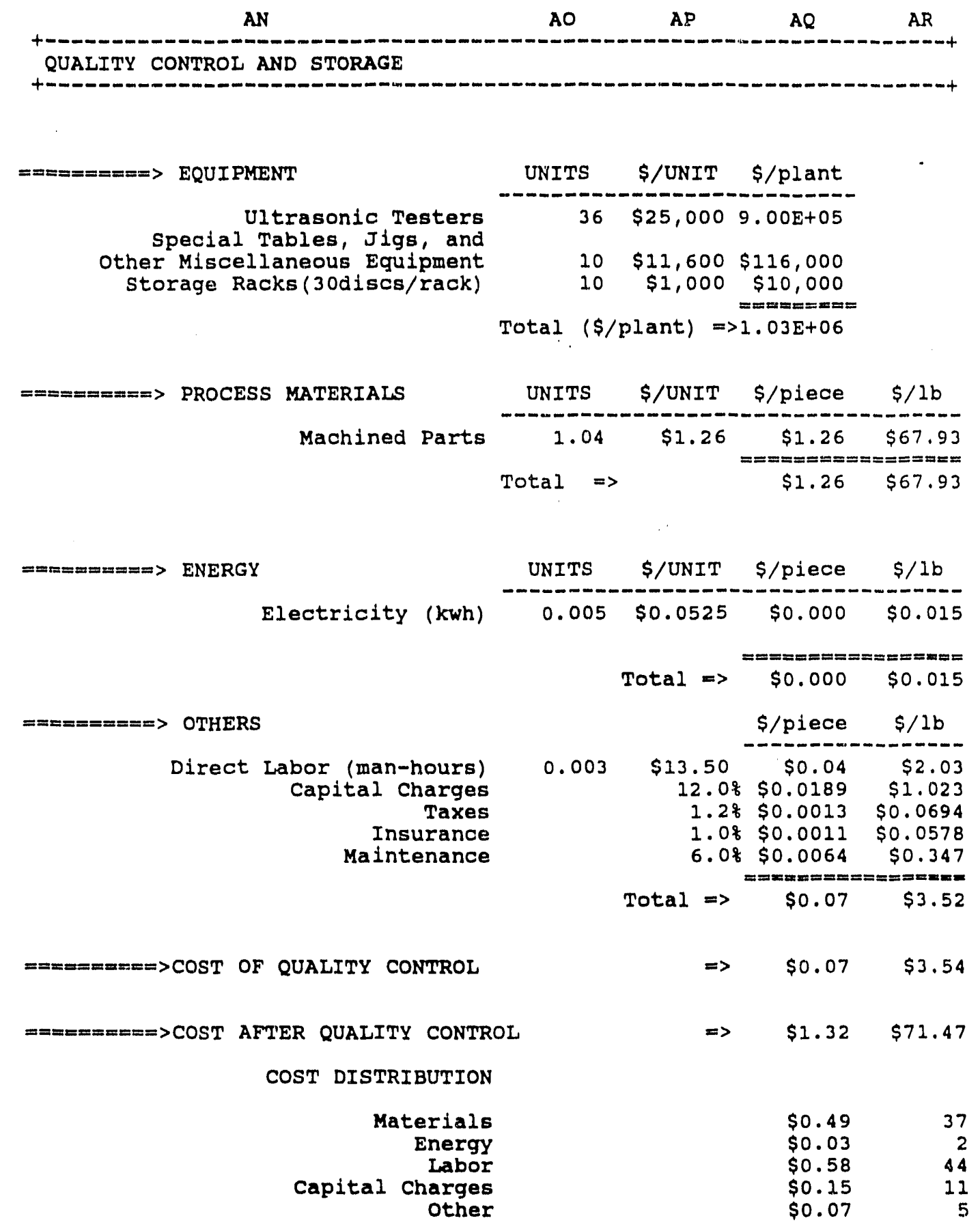




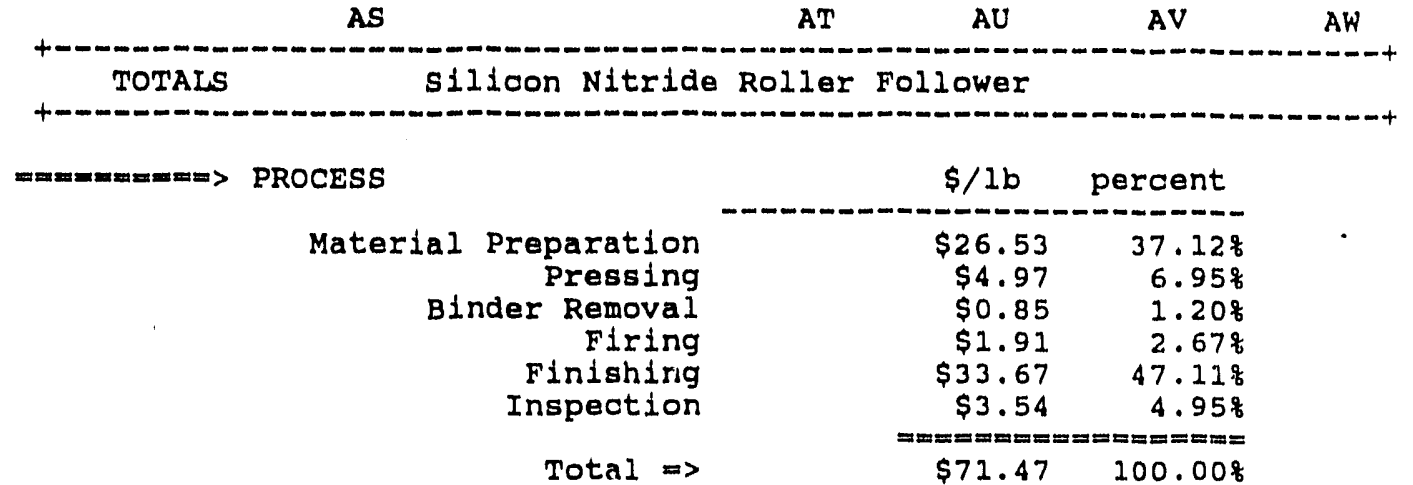

PROCESS COSTS

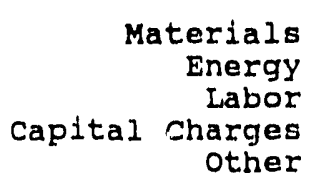

Total

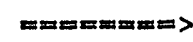

$\$ / k g$

$m=m=>$

ASSUMPTIONS

Powder Cost ( $\$ / 1 b)$

Firing Method

Firing Temperature ( $F)$

Hipping Temperature (C)

Machining Tolerance Total Yield

Production volume ( $\mathrm{PC} / \mathrm{Yr}$ )

Materials Capital Charges

Energy

Labor

other
$\$ 71.47 \quad 100.008$

\begin{tabular}{crr}
$\$ /$ piece & $\$ / 1 b$ & Percent \\
\hline$\$ 0.49$ & $\$ 26.54$ & 37.1 \\
$\$ 0.03$ & $\$ 1.57$ & 2.2 \\
$\$ 0.58$ & $\$ 31.45$ & 44.0 \\
$\$ 0.15$ & $\$ 8.14$ & 11.4 \\
$\$ 0.07$ & $\$ 3.77$ & 5.3 \\
$======================$ \\
$\$ 1.32$ & $\$ 71.47$ &
\end{tabular}

$\$ 157.23$

$\$ 20.00$

3452

1500

0.005

$88 \%$

$1.00 E+07$

$\begin{array}{rrr}\$ 0.49 & \$ 26.54 & 37.1 \\ \$ 0.15 & \$ 8.14 & 11.4 \\ \$ 0.03 & \$ 1.57 & 2.2 \\ \$ 0.58 & \$ 31.45 & 44.0 \\ \$ 0.07 & \$ 3.77 & 5.3\end{array}$


THE COST OF SILICON NITRIDE POWDER:

WHAT MUST IT BE TO COMPETE?

\begin{abstract}
APPENDIX B
MODEL ASSUMPTIONS AND INPUT PARAMETERS

FOR THE TURBOCHARGER ROTOR MODEL
\end{abstract}




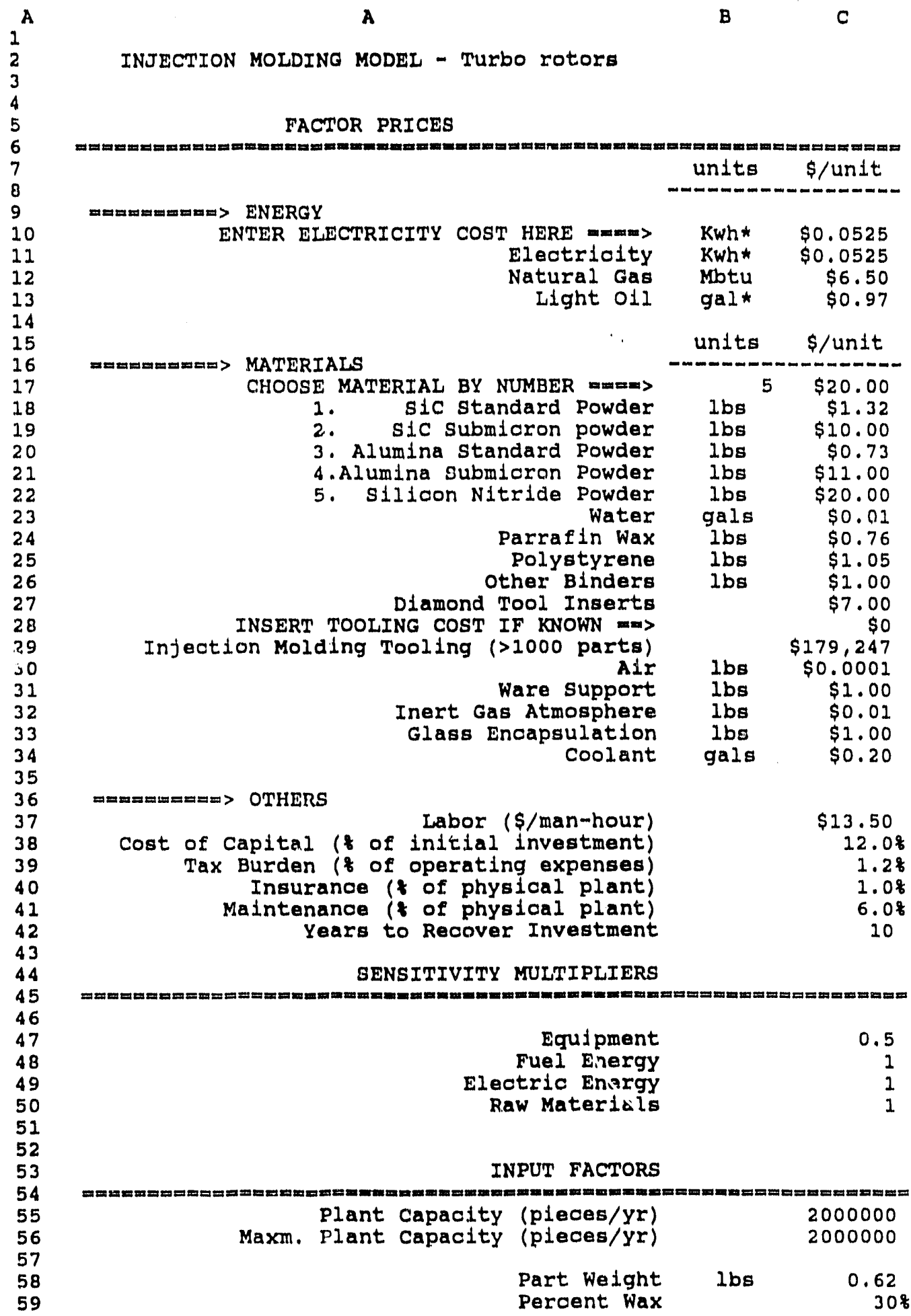


A

peroent plastios

Tool Iffe

Geometrio Factor ( $1=81$ mple, 2 medium, 3 muomplex) Difflaulty Faator - Funation of Welght Grinding Insert Iffe

VOLUMES

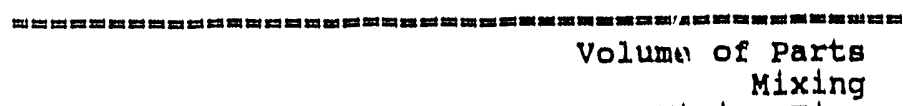

Mixing Time

Injection Molding Cyole Time Lathe (hand operated)

Lathe CNC (tooled)

Inspection

ASSUMED PROCESS YIELDS

Material Usage

** Not Used ** Parts Volume over Injection Molding ** Not Used ** Green Machining Binder Removal sintering Grinding Inspection Total Yield Teahnology yield Factor (1 to 9) INPUT FACTORS

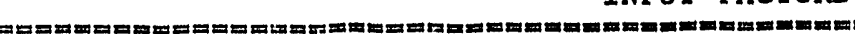
BINDER REMOVAL PARAMETERS

Weight of Ware support Green Density Specific Heat Binder volume $(t)$ Relative Humldity Entrance Entrance Air Temperature Exit Air Temperature Drying Heat Efflciency Binder Removal Time CHOOSE BINDER REMOVAL TIME $\Rightarrow$ Molding Temperature FIRING PARAMETERS

Thickness of Insulation Time at Temp. Firing Temperature Amblent Temperature Firing Heat efficiency (Continuous) Firing Heat Efficlency (Periodic) Firing Heat Effloiency (HIP)

CHOOSE FIRING METHOD $=m=>$ 1. Periodio 2. Continuous $\star \star \star$ Not Used $* \star \star 3$.

MACHINING COST AS A FUNCTION OF TOLERANCE
B

pleces 100000

hrs

4.4

$\begin{array}{cr} & 20000 \\ \mathrm{Ib} / \mathrm{hr} & 19 \\ \mathrm{hr} & 6 \\ \mathrm{sec} / \mathrm{lb} & 1.79 \\ \mathrm{parts} / \mathrm{hr} & 12 \\ \mathrm{parts} / \mathrm{hr} & 3.0 \\ \mathrm{parts} / \mathrm{hr} & 60\end{array}$


A

120

121

122

123

124

125

126

127

128

129

130

131

1.32

133

134

135

136

137

138

139

140

141

142

143

144

145

146

147

148

.1.49

150

151

152

153

154

155

156

157

158

159

160

161

162

163

164

165

166

167

168

169

170

171

172

173

174

175

176

177
A

INPUT TOLERANCE HERE (\#) $=m=$

$$
\text { Material Removed }
$$

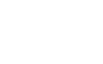

1.

2

3.

4.

5.
B

ou $1 n^{1}$

in

$\frac{\ln }{0.02}$

0.02

0.005

0.002

0.001

0.0005

OPTIONAL STAGES (Off=0/ON=1)

Green Machining

Final Finishing

* Final Finlshing tnoludes flash sprue removal *

C

$20 \%$

0.40

$\mathrm{mm}$

0.508

0.254

0.127

0.051

0.025

0.013

1

0

/xilecellpointer("width") $=9 \sim /$ wos9

(right) 


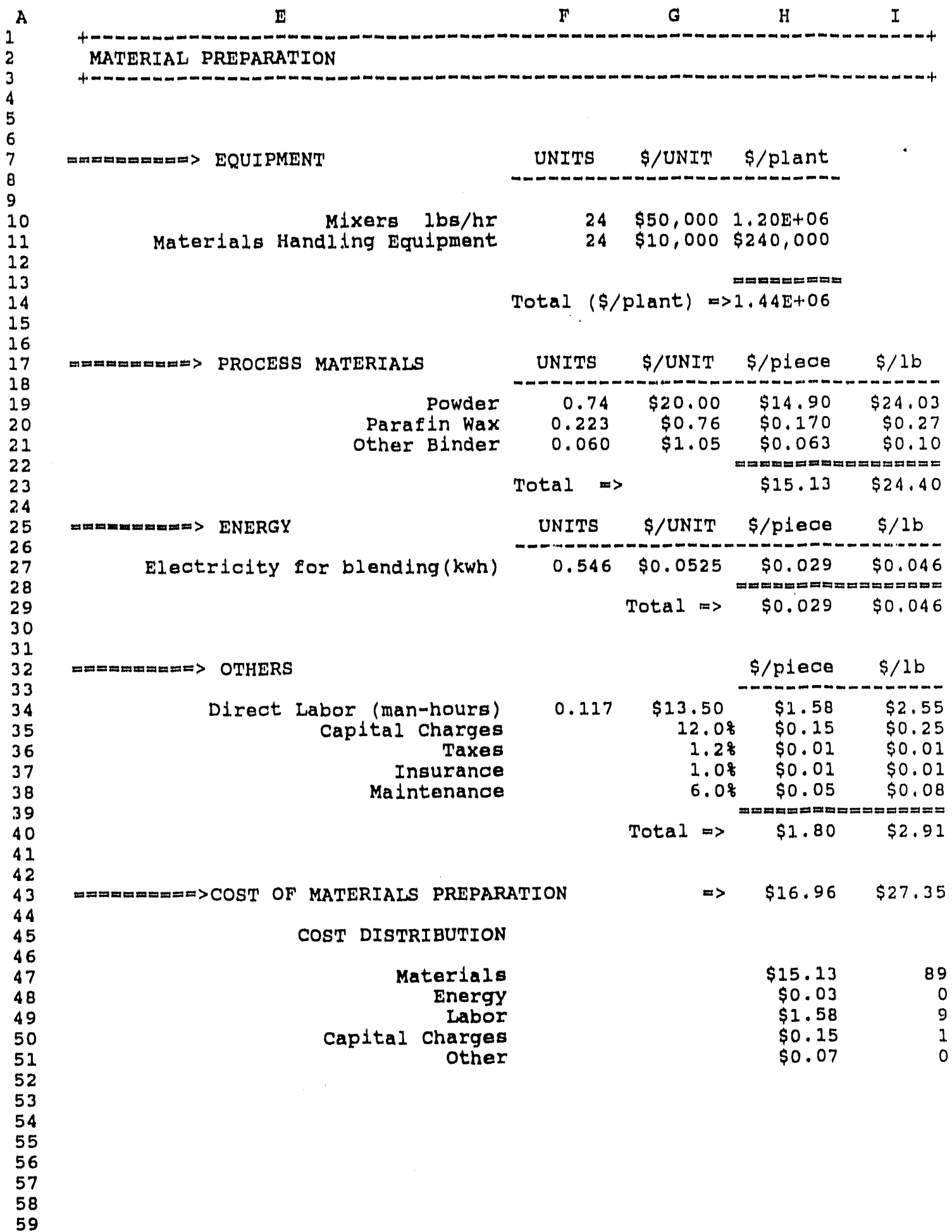




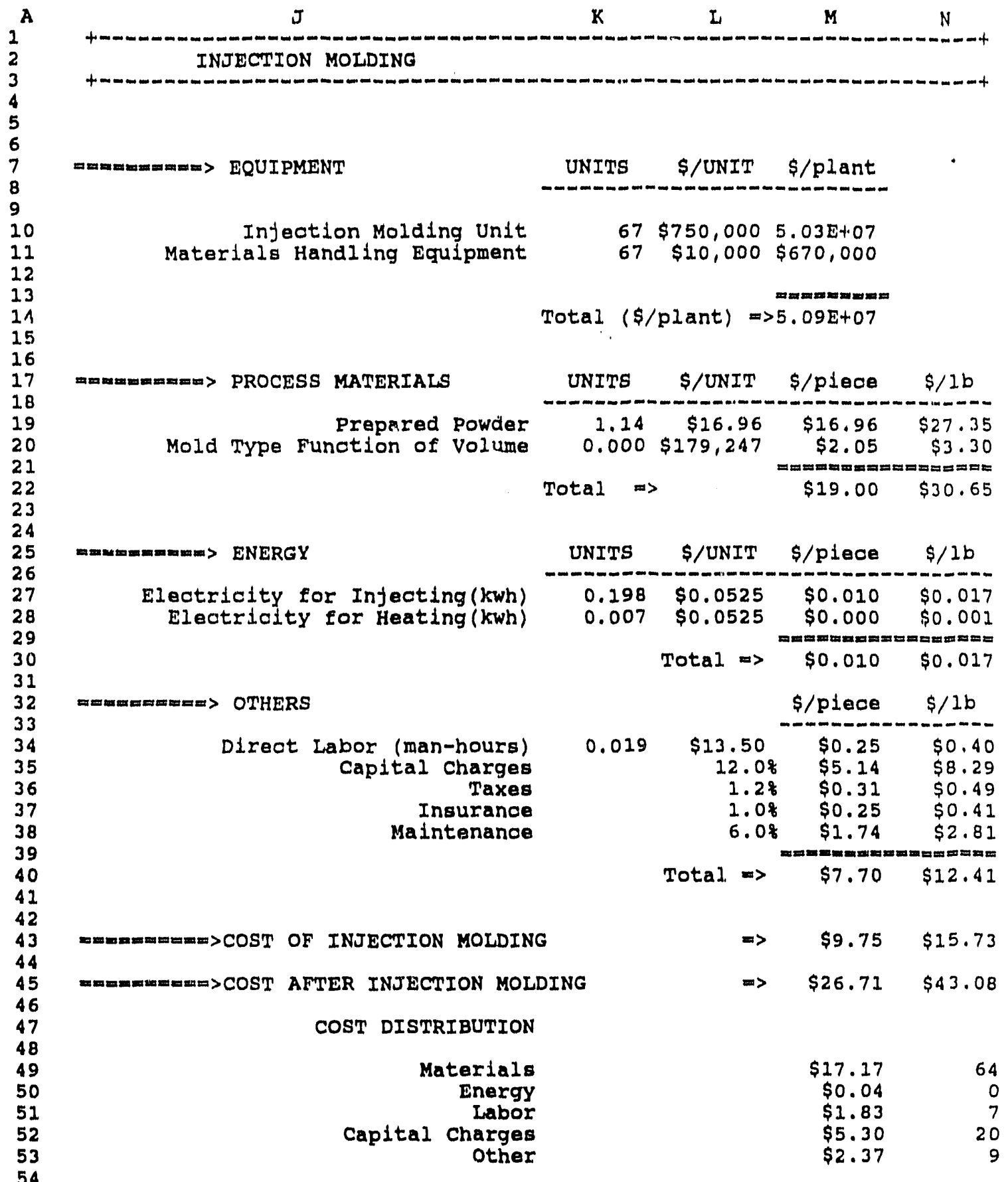




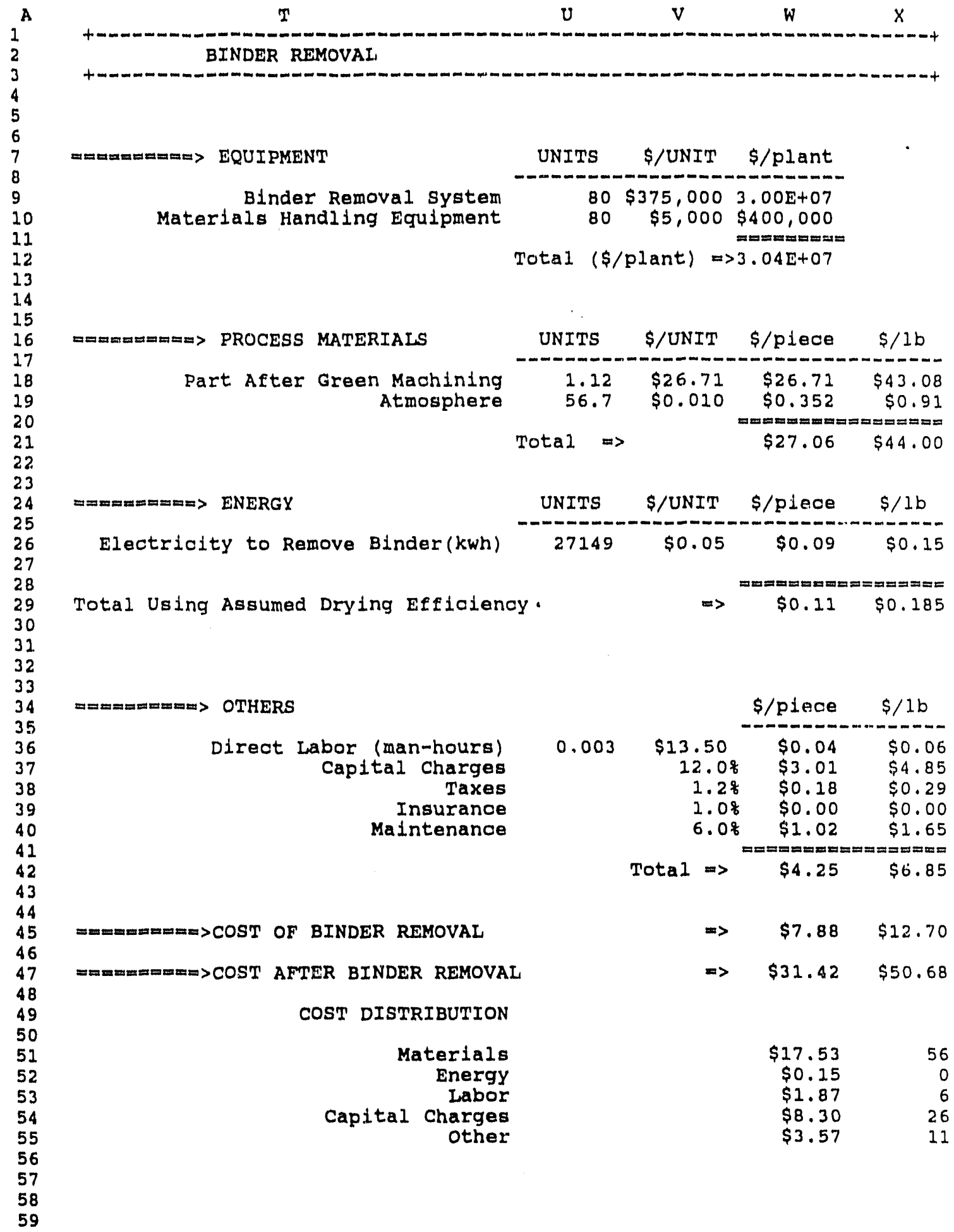




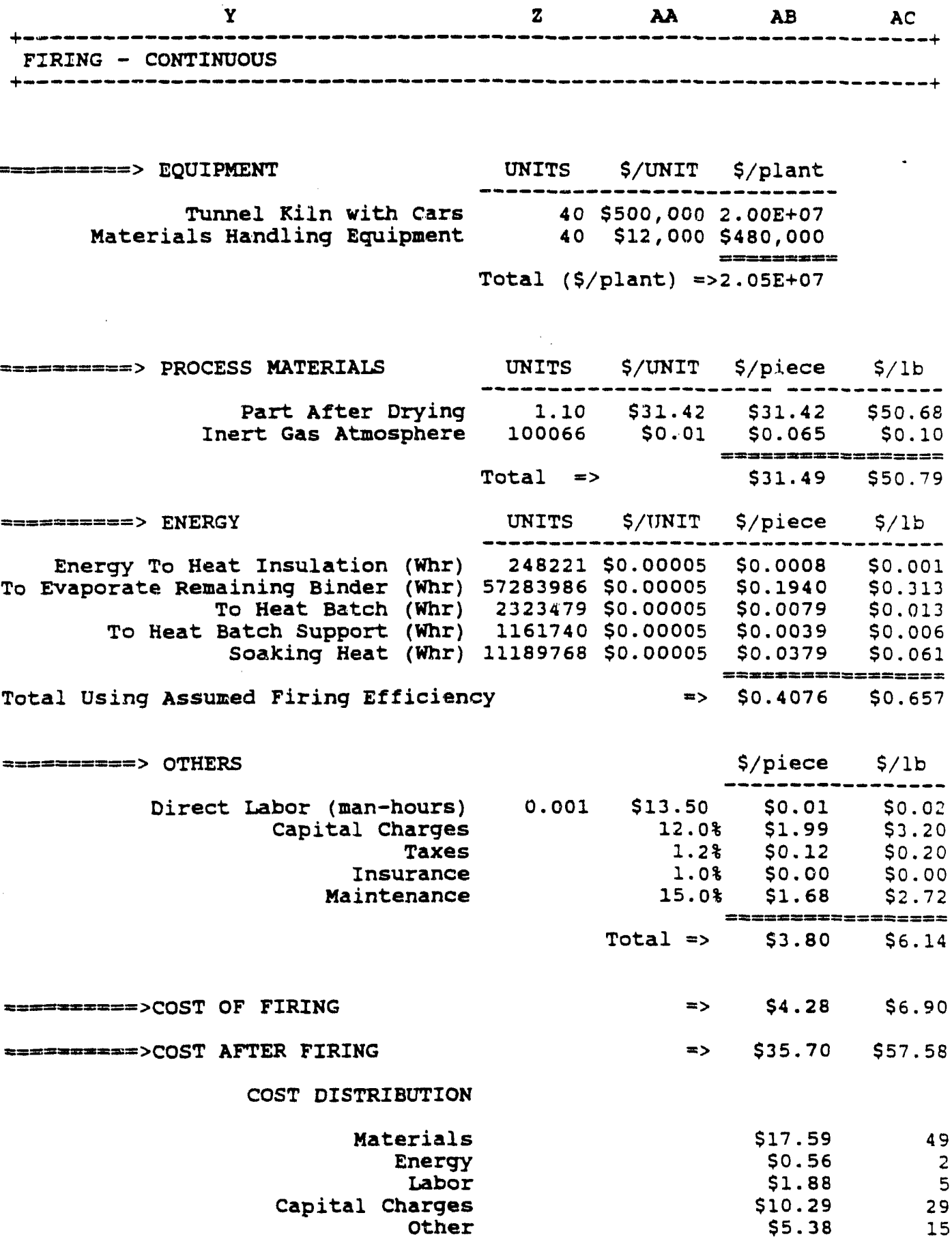




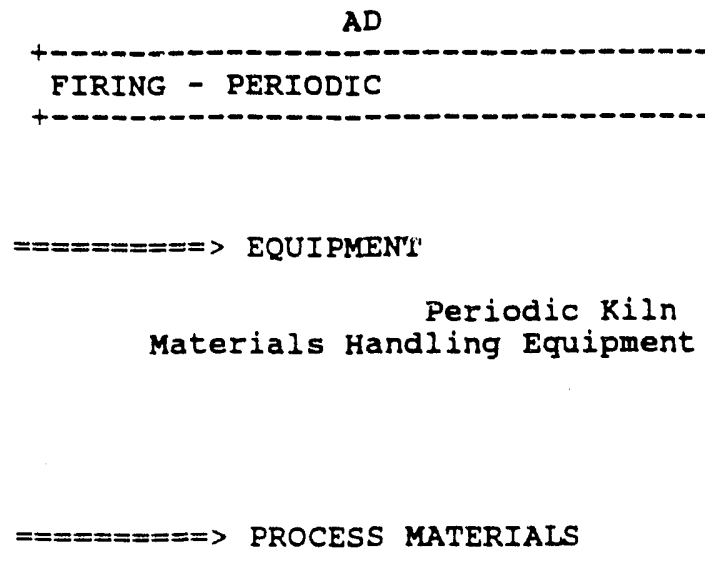

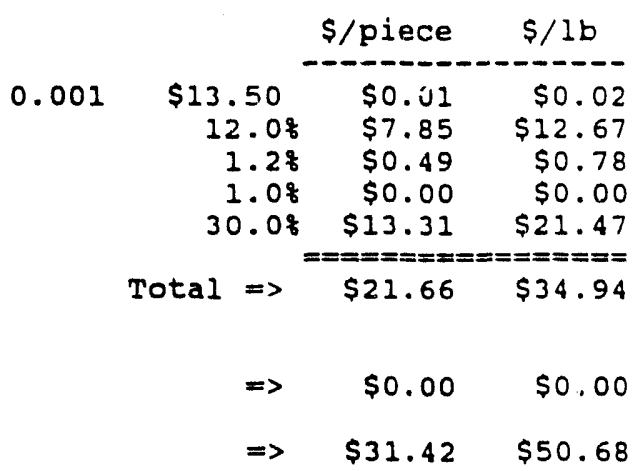

$\$ 17.53$

$\$ 0.15$

$\$ 1.87$

$\$ 8.30$

$\$ 3.57$ 


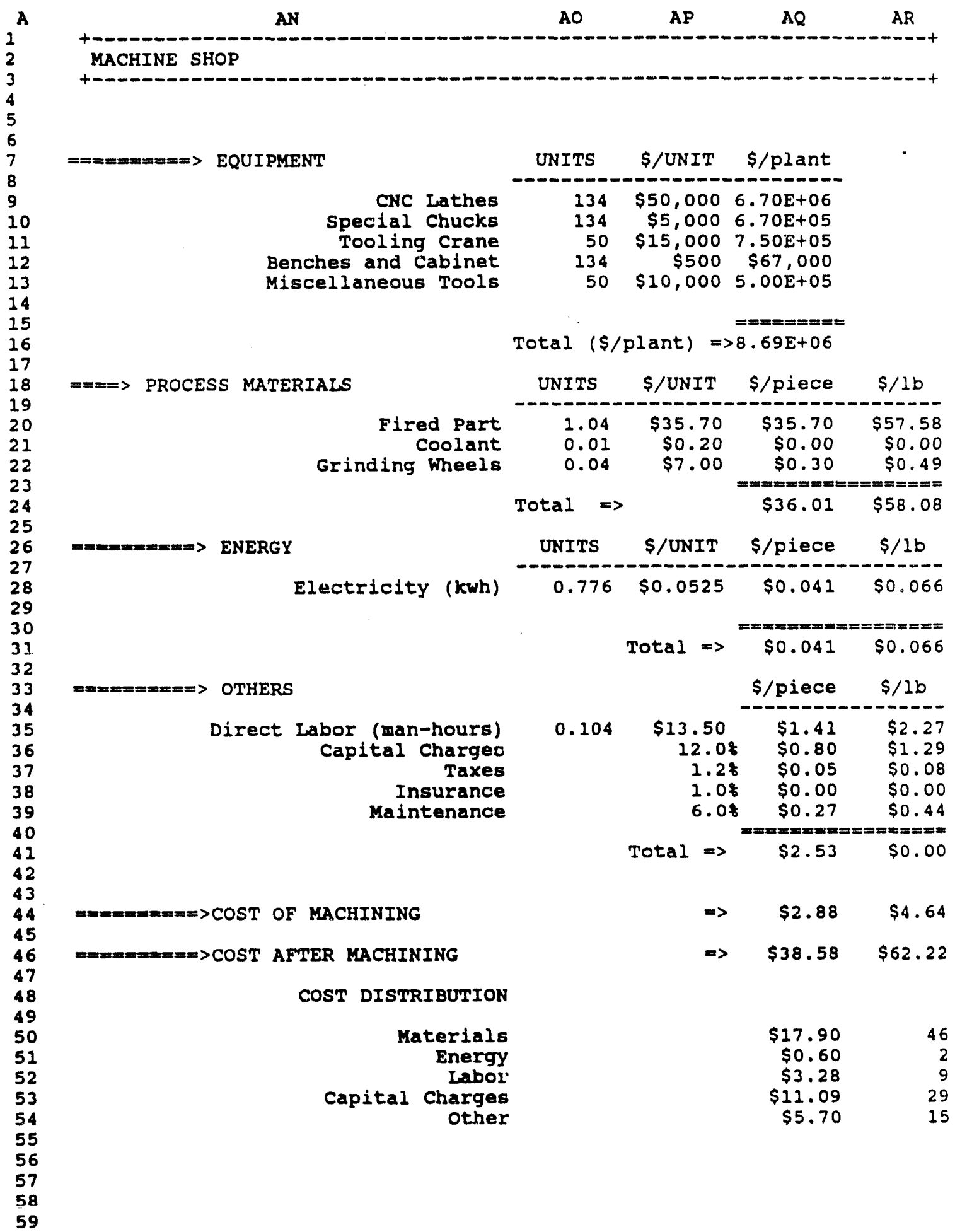




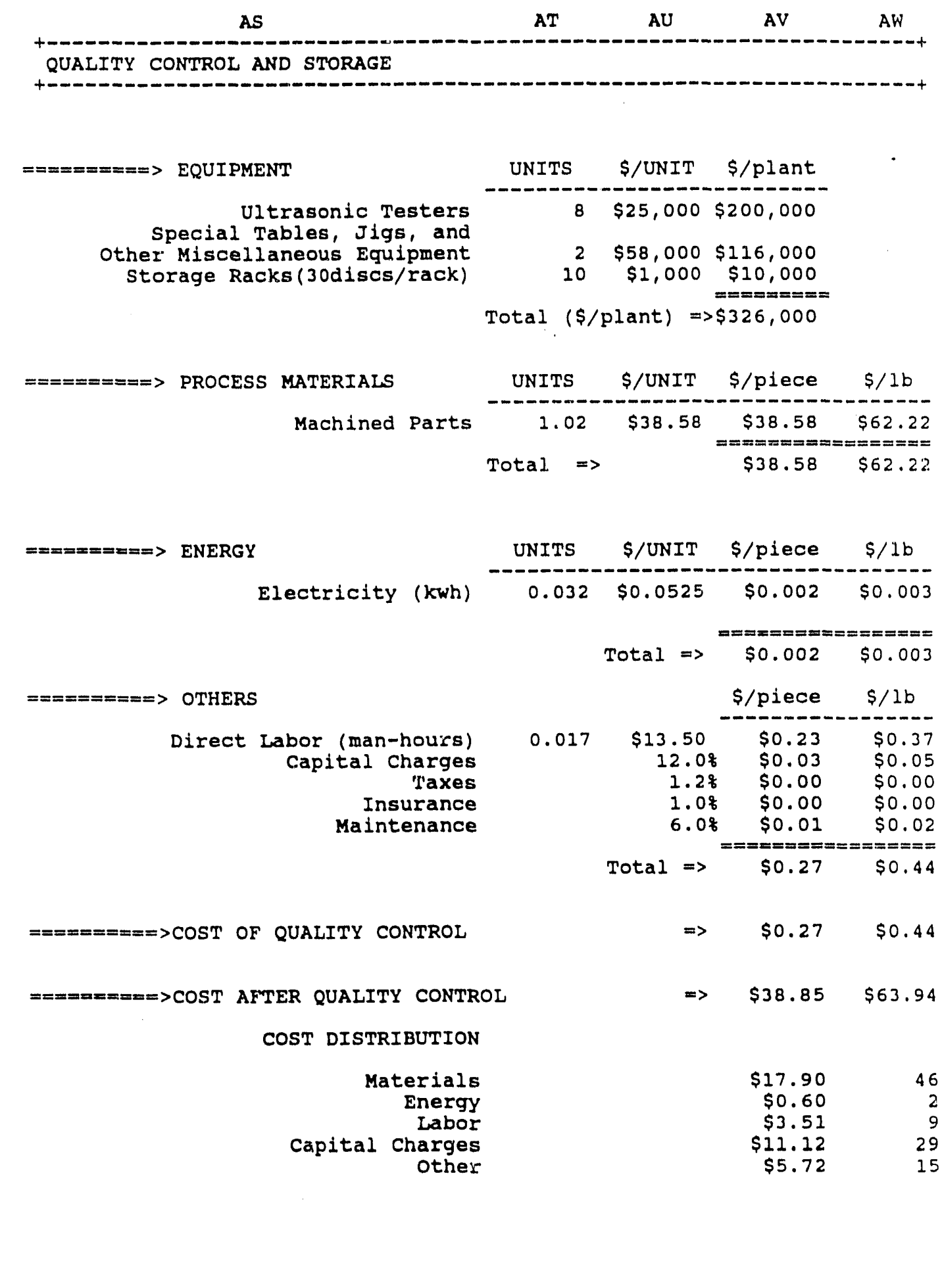




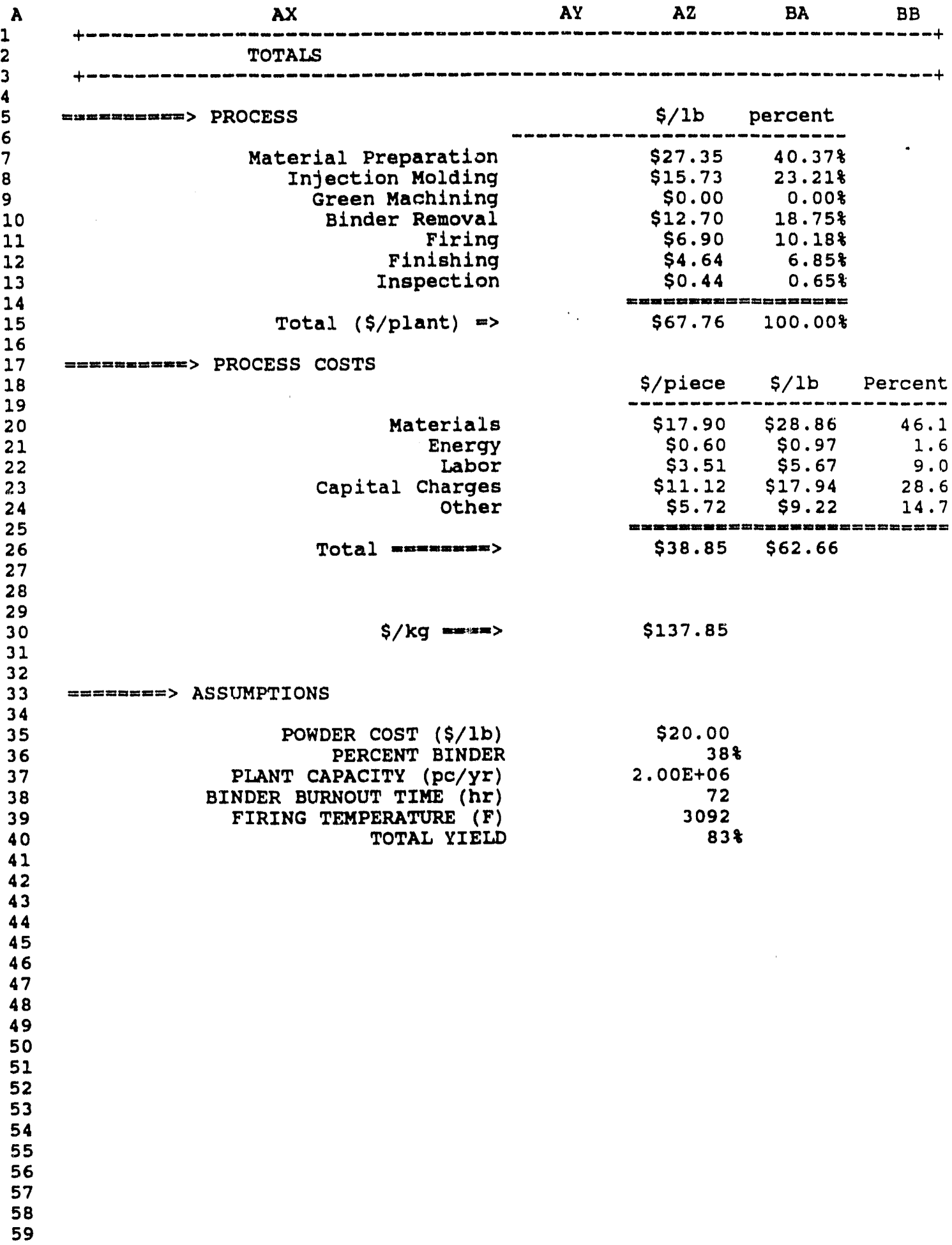




\section{INTERNAL DISTRIBUTION}

1. R. B. Braid

2. B. L. Bush

3. J. B. Cannon

4-9. T. R. Curlee

10-15. S. Das

16. P. S. Gillis

17. D. L. Greene

18. E. L. Hillsman

19. P. J. Hughes

20-25. D. R. Johnson

26. C. R. Kerley

27. J. O. Kolb

28. M. A. Kulisha

29. R. Lee
30. C. G. Rizy

31. D. E. Reichle

32. R. B. Shelton

33-38. S. G. Wilson

39. P. D. Witcher

40. ORNL Patent Office

41. Central Research Library

42. Document Reference Section

43-45. Laboratory Records

46. Laboratory Records - Record Copy

\section{EXTERNAL DISTRIBUTION}

47. Assistant Secretary for Conservation and Renewable Energy, Office of Transportation Technologies, U.S. Department of Energy, Washington, D.C.

48. B. Buchanan, Computer Science Department, University of Pittsburgh, 206 Mineral Industries Building, Pittsburgh, PA 15260.

49. A. Hirsch, Vice President, Environmental Sciences, Director, Washington Operations, Midwest Research Institute, 5109 Leesburg Pike, Suite 414, Falls Church, Virginia 22041.

50. H. M. Ingram, Director, Udall Center for Studies in Public Policy, The University of Arizona, 803/811 East First Street, Tucson, Arizona 85719.

51. C. D. MacCracken, President, Calmac Manufacturing Corporation, 101 West Sheffield Avenue, P.O. Box 710, Englewood, New Jersey 07631.

52. J. B. Shrago, Director, Office of Technology Transfer, 405 Kirkland Hall, Vanderbilt University, Nashville, Tennessee 37240.

53. M. Williams, Professor, Department of Economics, Northern Illinois University, DeKalb, IL 60115.

54. Office of Deputy Assistant Manager for Energy Research and Development, DOE-ORO, P.O. Box 2008, Oak Ridge, TN 37831-6269.

55-64. OSTI, U.S. Department of Energy, P.O. Box 62, Oak Ridge, TN 37831. 
